\title{
Post-depositional formation of vivianite-type minerals alters sediment phosphorus records
}

\author{
Nikki Dijkstra ${ }^{1, \mathrm{a}}$, Mathilde Hagens ${ }^{1, \mathrm{~b}}$, Matthias Egger $^{1, \mathrm{c}}$, and Caroline P. Slomp ${ }^{1}$ \\ ${ }^{1}$ Department of Earth Sciences - Geochemistry, Faculty of Geosciences, Utrecht University, \\ P.O. Box 80021, 3508 TA Utrecht, the Netherlands \\ anow at: Hoogheemraadschap De Stichtse Rijnlanden, Poldermolen 2, 3994 DD Houten, the Netherlands \\ ${ }^{b}$ now at: Soil Chemistry and Chemical Soil Quality, Wageningen University, P.O. Box 47, 6700 AA Wageningen, \\ the Netherlands \\ ${ }^{c}$ now at: The Ocean Cleanup Foundation, Martinus Nijhofflaan 2, 2624 ES Delft, the Netherlands
}

Correspondence: Caroline P. Slomp (c.p.slomp@uu.nl)

Received: 12 July 2017 - Discussion started: 31 August 2017

Revised: 10 December 2017 - Accepted: 28 December 2017 - Published: 12 February 2018

\begin{abstract}
Phosphorus (P) concentrations in sediments are frequently used to reconstruct past environmental conditions in freshwater and marine systems, with high values thought to be indicative of a high biological productivity. Recent studies suggest that the post-depositional formation of vivianite, an iron(II)-phosphate mineral, might significantly alter trends in $\mathrm{P}$ with sediment depth. To assess its importance, we investigate a sediment record from the Bornholm Basin that was retrieved during the Integrated Ocean Drilling Program (IODP) Baltic Sea Paleoenvironment Expedition 347 in 2013, consisting of lake sediments overlain by brackish-marine deposits. Combining bulk sediment geochemistry with microanalysis using scanning electron microscope energy dispersive spectroscopy (SEM-EDS) and synchrotron-based X-ray absorption spectroscopy (XAS), we demonstrate that vivianite-type minerals rich in manganese and magnesium are present in the lake deposits just below the transition to the brackish-marine sediments (at 11.5 to $12 \mathrm{~m}$ sediment depth). In this depth interval, phosphate that diffuses down from the organic-rich, brackish-marine sediments meets porewaters rich in dissolved iron in the lake sediments, resulting in the precipitation of iron(II) phosphate. Results from a reactive transport model suggest that the peak in iron(II) phosphate originally occurred at the lake-marine transition ( 9 to $10 \mathrm{~m}$ ) and moved downwards due to changes in the depth of a sulfidization front. However, its current position relative to the lake-marine transition is stable as the vivianite-type minerals and active sulfidization fronts have
\end{abstract}

been spatially separated over time. Experiments in which vivianite was subjected to sulfidic conditions demonstrate that incorporation of manganese or magnesium in vivianite does not affect its susceptibility to sulfide-induced dissolution. Our work highlights that post-depositional formation of iron(II) phosphates such as vivianite has the potential to strongly alter sedimentary $\mathrm{P}$ records particularly in systems that are subject to environmental perturbation, such as a change in primary productivity, which can be associated with a lake-marine transition.

\section{Introduction}

Phosphorus (P) is a key nutrient for marine organisms as it is essential for intracellular energy, cell growth and metabolism (Tyrrell, 1999). In marine waters, dissolved phosphate (henceforth denoted as $\mathrm{PO}_{4}$ ) is converted into particulate organic $\mathrm{P}$ by phytoplankton. Part of this particulate $P$ sinks through the water column as dead organic matter and is deposited onto the seafloor (Ruttenberg, 2003). In surface sediments below oxic bottom waters, $\mathrm{PO}_{4}$ that is released by the decomposition of organic matter typically diffuses back into the water column or is bound to iron oxyhydroxides ( $\mathrm{Fe}$ oxide-bound P). Most Fe oxides are dissolved by dissimilatory $\mathrm{Fe}(\mathrm{III})$ reduction or by reactions with hydrogen sulfide $\left(\mathrm{HS}^{-}\right.$) upon burial (Canfield et al., 1992), thereby releasing $\mathrm{PO}_{4}$ to the porewater. The subsequent accumulation of 
porewater $\mathrm{PO}_{4}$ at depth in the sediments can promote precipitation of P-bearing minerals such as apatites (authigenic calcium-P (Ca-P); mainly carbonate fluorapatite). This socalled "sink switching" acts as an efficient $\mathrm{P}$ trap in sediments and limits the diffusive flux of $\mathrm{PO}_{4}$ towards the water column (Ruttenberg and Berner, 1993; Slomp et al., 1996). As a consequence, sedimentary $\mathrm{P}$ concentrations can be a measure of the organic matter supply to the sediment (Calvert and Pedersen, 2007; Tribovillard et al., 2006). Trends in sedimentary $\mathrm{P}$ with sediment depth have, for instance, been used as evidence that upwelling zones were more productive during interglacial stages compared to glacial stages (Ganeshram et al., 2002).

In sediments overlain by hypoxic or anoxic bottom waters (oxygen concentrations below $2 \mathrm{mg} \mathrm{L}^{-1}$ or absent, respectively), $\mathrm{P}$ is generally less efficiently retained in the surface sediments. This is due to the absence of Fe oxides that can adsorb P (Slomp et al., 1996) and other redoxdependent mechanisms, such as the decreased sequestration of polyphosphates in sediments overlain by anoxic waters (Sannigrahi and Ingall, 2005) and the preferential regeneration of $\mathrm{P}$ from organic matter (Ingall et al., 1993; Ingall and Jahnke, 1997; Jilbert et al., 2011). Less retention of $\mathrm{P}$ in surface sediments can hamper buildup of porewater $\mathrm{PO}_{4}$ in the sediments and sink switching of $\mathrm{P}$ to P-bearing minerals, resulting in less burial of $\mathrm{P}$ relative to organic carbon $\left(\mathrm{C}_{\mathrm{org}}\right)$. Trends in the ratio of $\mathrm{C}_{\text {org }}$ to total $\mathrm{P}\left(\mathrm{C}_{\text {org }} / \mathrm{P}\right)$ with sediment depth thus can reflect bottom-water redox conditions. This has been demonstrated for various environments and on various timescales, ranging from the Phanerozoic ocean (Algeo and Ingall, 2007) and the Quaternary Mediterranean (Kraal et al., 2010) to the modern Black Sea (Dijkstra et al., 2014) and Baltic Sea (Jilbert and Slomp, 2013).

Besides sedimentary $\mathrm{P}$ concentrations and $\mathrm{C}_{\mathrm{org}} / \mathrm{P}$ ratios, the occurrence of vivianite $\left(\left(\mathrm{Fe}_{3} \mathrm{PO}_{4}\right)_{2} \cdot 8 \mathrm{H}_{2} \mathrm{O}\right)$ in sediments is also used in reconstructions of paleo-environmental conditions in lake and marine basins (e.g., Derkachev et al., 2007; Kalnina et al., 2000; Taldenkova et al., 2010). These $\mathrm{Fe}(\mathrm{II})$ phosphates can precipitate in surface sediments with sulfide-depleted porewaters that are rich in both $\mathrm{Fe}^{2+}$ and $\mathrm{PO}_{4}$ (Berner, 1981; Nriagu and Dell, 1974; Nriagu, 1972). The presence of vivianite in sediments may therefore reflect anoxic non-sulfidic bottom waters upon sediment deposition. The large vivianite concretions $(>500 \mu \mathrm{m})$ in Late Glacial and Holocene sediments from the Laptev Sea are, for example, assumed to be the result of low bottom-water oxygen upon sediment deposition (Taldenkova et al., 2010). Vivianite minerals that were discovered in the presence of organic matter and iron sulfides in marine Latvian sediments from the middle Pleistocene were also linked to oxygen-poor bottom waters at the time of deposition (Kalnina et al., 2000).

Post-depositional processes during burial can, however, alter the geochemical signature of sediments. An active downward oxidation front, for instance, can reoxygenate former anoxic organic-rich sediments, resulting in a decrease in
$\mathrm{C}_{\text {org }} / \mathrm{P}$ ratios as $\mathrm{C}_{\text {org }}$ is remineralized, while the released $\mathrm{P}$ is retained in the sediments (Slomp et al., 2002). Postdepositional diagenesis can also result in the precipitation of vivianite in sediments. This is known to occur below the sulfate/methane transition zone (SMTZ) in sediments, where porewater $\mathrm{Fe}^{2+}$ can accumulate in the absence of sulfide and react with porewater $\mathrm{PO}_{4}$ (Egger et al., 2015b, 2016; Hsu et al., 2014; März et al., 2008). Vivianite can also form post-depositionally at lake-marine transitions, where upward-diffusing porewater $\mathrm{Fe}^{2+}$ from lake deposits meets $\mathrm{PO}_{4}$ from the overlying organic-rich marine deposits, as recently confirmed by microspectroscopy in sediments from the Landsort Deep (Baltic Sea; Dijkstra et al., 2016). Postdepositional vivianite authigenesis is also assumed to have caused a distinct $\mathrm{P}$ maximum $\left(\sim 60 \mu \mathrm{molg}^{-1}\right)$ at the lakemarine transition in coastal Bothnian Sea sediments (Dijkstra et al., 2017a). The occurrence of vivianite in sediments can thus not always be ascribed to the environmental conditions in the surface sediments and overlying waters upon deposition.

Diagenesis can also result in the dissolution of depositional or post-depositional vivianite in sediments, as this Pbearing mineral is assumed to dissolve in the presence of even small concentrations of sulfide (Vuillemin et al., 2013). Recently, sulfide-induced dissolution of vivianite was included in a reactive transport model for deep basin sediments in the Black Sea and significantly improved the model fits for porewater $\mathrm{PO}_{4}$ and $\mathrm{Fe}^{2+}$, as well as for sedimentary $\mathrm{P}$ (Egger et al., 2016). This Black Sea case study showed that diffusion of sulfide into lake sediments can result in a continuous downward-migrating vivianite front just below the sulfidization front. Over the past 7500 years, the peak in vivianite in these Black Sea sediments may have migrated downwards from its initial position at the lake-marine transition over a distance of more than $2 \mathrm{~m}$ (Egger et al., 2016). In contrast to the Black Sea, the Landsort Deep in the Baltic Sea was only intermittently sulfidic throughout the Holocene and vivianite is preserved close to the lake-marine transition (Dijkstra et al., 2016). The sediment depth at which post-depositional vivianite can overprint paleo-records of total $\mathrm{P}$ and $\mathrm{C}_{\text {org }} / \mathrm{P}$ may thus depend on the porewater sulfide concentrations during sediment burial.

Also, other factors might affect the stability and, subsequently, the presence of vivianite in sediments. In many lake and marine sediments, vivianite aggregates are enriched in magnesium (Mg) and manganese (Mn) (Dijkstra et al., 2016; Egger et al., 2015b; Hsu et al., 2014). These enrichments may reflect the substitution of $\mathrm{Fe}^{2+}$ by $\mathrm{Mn}^{2+}$ and $\mathrm{Mg}^{2+}$ in the crystal structure of vivianite (Dijkstra et al., 2016; Frost et al., 2002; Nakano, 1992). In Fe oxides, the incorporation of cations such as $\mathrm{Mn}^{3+}$ into the crystal structure affects the mineral stability and can result in higher acid dissolution rates of $\mathrm{Fe}$ oxides (Alvarez et al., 2007). At present, it is unknown whether the substitution of $\mathrm{Fe}^{2+}$ in vivianite crystals 
by other cations affects the mineral stability and its susceptibility to sulfide dissolution.

In this study, we investigate the post-depositional formation of vivianite-type minerals in sediments of a hypoxic basin in the Baltic Sea, the Bornholm Basin. Combining various types of geochemical analyses (e.g., total elemental analysis, P extractions, reactive transport modeling), we demonstrate that vivianite-type minerals began to precipitate below the lake-marine transition in the Bornholm Basin after the seawater intrusion. Mineral authigenesis at depth resulted in a doubling of the total $\mathrm{P}$ concentrations in our sediments, thereby significantly altering the $\mathrm{P}$ burial record. With a sulfidization experiment, we confirm that vivianite rapidly dissolves under sulfidic conditions and show that its susceptibility to sulfide-induced dissolution does not seem affected by the incorporation of $\mathrm{Mn}$ or $\mathrm{Mg}$ in the mineral.

\section{Methods}

\subsection{Study site, coring and lithology}

The Baltic Sea is a semi-enclosed basin in which the water column salinity is strongly affected by changes in sea level (Björck, 1995). The basin was a freshwater environment (the Ancylus Lake) before the intrusion of North Sea water approximately 8900 years ago. This intrusion was followed by a gradual transition to more saline conditions and the establishment of the Littorina Sea $(\sim 8000$ years ago; Andrén et al., 2011; Sohlenius et al., 2001). Large parts of the Baltic Sea experienced bottom-water hypoxia $\sim 7000-4000$ years ago during the Holocene Thermal Maximum. This is assumed to be the result of the inflow of North Sea water and warmer sea surface temperatures, which together may have caused water column stratification and the subsequent development of widespread hypoxia in the Baltic Sea (Zillén et al., 2008).

The Bornholm Basin is located in the central Baltic Sea (Fig. 1) and is currently characterized by a surface water salinity of 7-8 and a deep water salinity of 16-20 (Mohrholz et al., 2006). At present, the bottom waters are seasonally hypoxic with minimum oxygen concentrations below $0.5 \mathrm{mg} \mathrm{L}^{-1}$ (Mohrholz et al., 2006). Sediment cores were recovered from three holes $(\mathrm{A}-\mathrm{C})$ at station M0065 in the Bornholm Basin during the Integrated Ocean Drilling Pro-

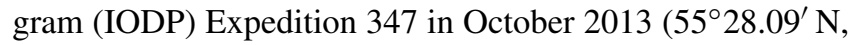
$15^{\circ} 28.63^{\prime} \mathrm{E}$; water depth: $\left.84.3 \mathrm{~m}\right)$. We applied the midcomposite depth scale as reported in the proceedings of the expedition (mcd; Andrén et al., 2015). The upper $2 \mathrm{~m}$ of sediment were not sampled due to the risk of mustard gas contamination. A multicore was recovered from the same location in June 2016 during a research cruise with RV Pelagia for additional porewater analyses $(0-50 \mathrm{~cm}$ sediment depth).

The lowest part of the long sediment record (below $\sim 13.5 \mathrm{mcd}$ ) consists of greyish-brown to dark grey clays

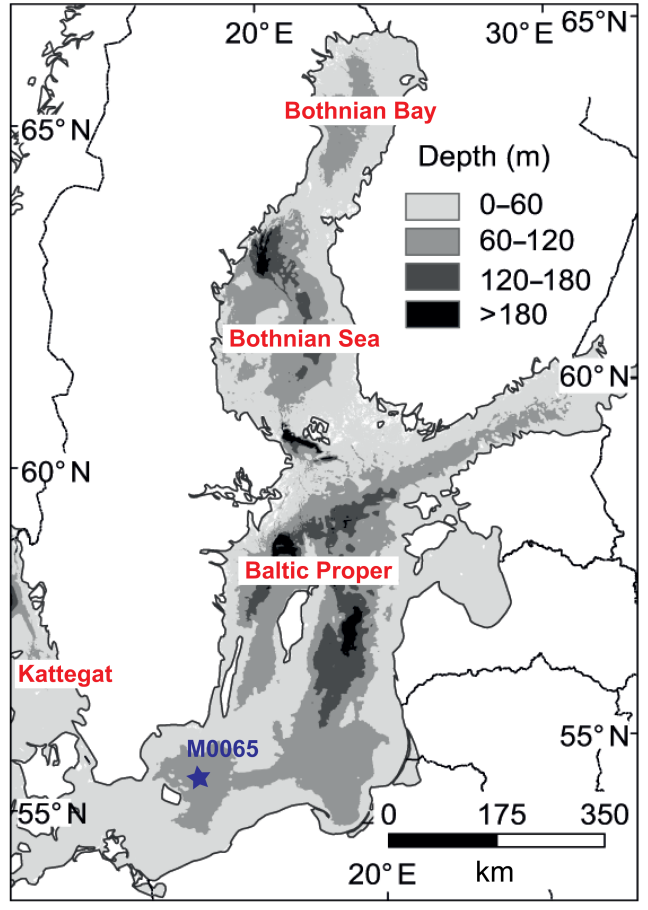

Figure 1. Map of the major basins in the Baltic Sea with our study site (M0065) in the Bornholm Basin.

with a down-core increase in the silt and sand fraction. These sediments are overlain by grey clays of which the upper part is dominated by iron sulfide laminations. The top sediments are composed of organic-rich clays containing fragments of bivalve shells and organic remnants $(<9.65$, $<9.85$ and $<9.69$ mcd for holes A, B and C, respectively). These organic-rich clays contain benthic foraminifers and brackish-marine diatom species, whereas the deeper sediments are generally characterized by freshwater diatom taxa and the absence of benthic foraminifera. These shifts in lithology and biostratigraphy mark the lake-marine transition between $\sim 9$ and 10 mcd. A detailed description of the lithology and biostratigraphy can be found in Andrén et al. (2015).

\subsection{Porewater analysis}

Porewater was collected and filtered during the IODP 347 expedition using rhizons or squeezers $(0.2 \mu \mathrm{m}$ pore size $)$. Alkalinity was calculated by the method of Grasshoff et al. (1983) after titration with $0.01 \mathrm{M} \mathrm{HCl}$. Dissolved inorganic carbon (DIC) was measured in samples poisoned with saturated $\mathrm{HgCl}_{2}$ using an AS-C3 analyzer (Apollo SciTech) that consisted of an acidification and purging unit in combination with a $\mathrm{CO}_{2} / \mathrm{H}_{2} \mathrm{O}$ analyzer (LI-COR 7000). The conductivity method in Hall and Aller (1992) was used to determine ammonium concentrations $\left(\mathrm{NH}_{4}^{+}\right)$in the porewaters, and dissolved sulfide (denoted as $\mathrm{HS}^{-}$) was measured using 
Table 1. Details on the Fe extraction method by Poulton and Canfield (2005): chemical solutions and targeted phases.

\begin{tabular}{lllll}
\hline Steps & Extractant & Time & Target phase & Term \\
\hline I & $1 \mathrm{M}$ sodium acetate brought to $\mathrm{pH} 4.5$ with acetic acid & $24 \mathrm{~h}$ & Carbonate-associated Fe & Fe-carb \\
\hline II & $1 \mathrm{M}$ hydroxylamine- $\mathrm{HCl}$ in $25 \% \mathrm{v}: \mathrm{v}$ acetic acid & $48 \mathrm{~h}$ & Easily reducible Fe oxides, FeS ${ }^{\mathrm{a}} \mathrm{Fe}^{-o x} 1^{\mathrm{b}}$ \\
\hline III & $\begin{array}{l}50 \mathrm{~g} \mathrm{~L}^{-1} \text { sodium dithionite solution buffered to } \mathrm{pH} 4.8 \text { with } \\
0.35 \mathrm{M} \text { acetic acid } / 0.2 \mathrm{M} \text { sodium citrate }\end{array}$ & Crystalline Fe oxides & Fe-ox $2^{\mathrm{b}}$ \\
\hline IV & $0.2 \mathrm{M}$ ammonium oxalate $/ 0.17 \mathrm{M}$ oxalic acid & $2 \mathrm{~h}$ & Magnetite & $\mathrm{Fe}-\mathrm{mag}$ \\
\hline
\end{tabular}

a Some of the extracted Fe in this solution may represent FeS. ${ }^{b}$ The Fe-ox1 and Fe-ox 2 fractions together define the sedimentary Fe-oxide fraction in the sediment (Fe-ox; without magnetite).

the methylene blue method of Cline (1969). Porewaters were acidified and analyzed for $\mathrm{Mg}, \mathrm{P}, \mathrm{Ca}, \mathrm{Fe}$ and $\mathrm{Mn}$ by inductively coupled plasma - optical emission spectrometry (ICPOES) and are assumed to represent $\mathrm{Mg}^{2+}, \mathrm{PO}_{4}, \mathrm{Ca}^{2+}, \mathrm{Fe}^{2+}$ and $\mathrm{Mn}^{2+}$, respectively. Sulfate $\left(\mathrm{SO}_{4}^{2-}\right)$ and chloride $\left(\mathrm{Cl}^{-}\right)$ concentrations were determined by a Metrohm 882 compact ion chromatograph at the University of Bremen. Salinity was calculated from $\mathrm{Cl}^{-}$concentrations (Dickson et al., 2007). To determine concentrations of porewater methane $\left(\mathrm{CH}_{4}\right)$, $5 \mathrm{~cm}^{3}$ sediment samples were extruded in glass vials filled with $1 \mathrm{M} \mathrm{NaOH}$ solution, sealed and stored upside down for further analysis. After headspace injection $(250 \mu \mathrm{L})$, the $\mathrm{CH}_{4}$ concentrations were determined using an Agilent A7890 gas chromatograph. More details on the porewater procedures can be found in Andrén et al. (2015). The methods used to analyze porewaters from the multicore are described in Egger et al. (2016).

\subsection{Bulk sediment analysis}

Sediment samples were collected at a $2 \mathrm{~m}$ depth resolution immediately after core retrieval and stored in nitrogenpurged aluminum bags to prevent sample oxidation (hole C). Sediment samples were also collected at a $20 \mathrm{~cm}$ resolution during the onshore sampling campaign (hole A). The sediment record at and just below the lake-marine transition was studied in more detail using samples collected in November 2014 at the Bremen Core Repository $(5 \mathrm{~cm}$ resolution; hole $\left.\mathrm{A}_{\mathrm{HR}}\right)$. All sediment samples were freeze-dried and ground with an agate mortar and pestle at Utrecht University prior to further analysis.

Sediment subsamples $(0.125 \mathrm{~g})$ were dissolved overnight at $90^{\circ} \mathrm{C}$ in a mixture of hydrofluoric acid, nitric acid and perchloric acid. After evaporation of the acids at $140^{\circ} \mathrm{C}$, the residue was redissolved in a nitric acid solution $(1 \mathrm{M})$. Total concentrations of Mo, Fe, aluminum (Al), S, Mn, P, $\mathrm{Ca}$ and $\mathrm{Mg}$ in the solutions were determined by ICP-OES (Perkin Elmer Optima 3000). The relative standard deviation for all elements was generally less than $3 \%$ (laboratory reference material (ISE-921), in-house standards and sample replicates).
During the onshore sampling party at the Bremen Core Repository, $\mathrm{C}_{\text {org }}$ content was determined in decalcified sediment samples with a LECO CS-300 carbon-sulfur analyzer (holes A-C; see Andrén et al., 2015 for more details).

\subsection{Sequential $\mathrm{Fe}$ and $\mathrm{S}$ extractions}

We performed a sequential Fe extraction on dry sediment subsamples $(0.1 \mathrm{~g})$ from hole $\mathrm{C}$ according to the method of Poulton and Canfield (2005) in an oxygen-free atmosphere. The extractants to target the various Fe phases, i.e., carbonate-associated $\mathrm{Fe}$ (Fe-carb), easily reducible $\mathrm{Fe}$ oxides (Fe-ox1), crystalline $\mathrm{Fe}$ oxides (Fe-ox2) and magnetite (Fe-mag), are summarized in Table 1. The Fe-ox1 and Feox 2 fractions together define the sedimentary Fe-oxide fraction in the sediment (Fe-ox; without magnetite). The 1,10phenanthroline method was used to determine Fe concentrations in the solutions (APHA, 2005).

For the same set of sediment samples, we determined the acid volatile sulfide (AVS) and chromium-reducible sulfide (CRS) fractions with the $\mathrm{S}$ extraction method as developed by Burton et al. (2008). We used a $6 \mathrm{M} \mathrm{HCl} / 0.1 \mathrm{M}$ ascorbic acid solution and an acidic chromium(II) solution to convert sulfide in AVS and CRS into hydrogen sulfide gas. The gas was trapped in an alkaline zinc-acetate solution, in which the amount of sulfide was then measured by iodometric titration (APHA, 2005). The sediment samples were shielded from the atmosphere to avoid sample oxidation, using either a glovebox (AVS) or a nitrogen gas line (CRS). The AVS fraction is assumed to represent iron monosulfides $(\mathrm{FeS})$ and the CRS fraction is assumed to represent pyrite $\left(\mathrm{FeS}_{2}\right)$. The CRS concentrations (in $\mu \mathrm{mol} \mathrm{S} \mathrm{g}{ }^{-1}$ were divided by 2 to represent concentrations of $\mathrm{FeS}_{2}$ (in $\mu$ mol FeS $\mathrm{g}^{-1}$ ). The relative standard deviations were generally below $10 \%$ for both the $\mathrm{Fe}$ and $\mathrm{S}$ extractions, based on replicates and in-house standards.

\subsection{Bulk phosphorus analysis (SEDEX and P XANES)}

The $\mathrm{P}$ fractionation in ground sediment subsamples $(0.1 \mathrm{~g})$ was investigated with the sequential extraction (SEDEX) method (Ruttenberg, 1992), as modified by Slomp et 
Table 2. Chemical solutions, targeted phases and terms of the sequential extraction (SEDEX; Ruttenberg, 1992) method, including the modifications by Slomp et al. (1996).

\begin{tabular}{|c|c|c|c|c|}
\hline Steps & Extractant & Time & Target phase & Term \\
\hline I & $1 \mathrm{M} \mathrm{MgCl}_{2}(\mathrm{pH} 8)$ & $0.5 \mathrm{~h}$ & Exchangeable P & Ex-P \\
\hline $\mathrm{II}_{\mathrm{a}}$ & $\begin{array}{l}\text { CDB solution (pH 7.6) : } 0.3 \mathrm{M} \mathrm{Na}_{3} \text { citrate; } \\
25 \mathrm{~g} \mathrm{~L}^{-1} \mathrm{Na} \text { dithionite; } 1 \mathrm{M} \mathrm{NaHCO}_{3}\end{array}$ & $8 \mathrm{~h}$ & P bound to Fe oxides, $\mathrm{Fe}(\mathrm{II})$ phosphates $^{\mathrm{a}}$ & $\mathrm{Fe}-\mathrm{P}$ \\
\hline $\mathrm{II}_{\mathrm{b}}$ & $1 \mathrm{M} \mathrm{MgCl}_{2}(\mathrm{pH} 8)$ & $0.5 \mathrm{~h}$ & Washing step & \\
\hline $\mathrm{III}_{\mathrm{a}}$ & $1 \mathrm{MNa}$ acetate buffered to $\mathrm{pH} 4$ with acetic acid & $6 \mathrm{~h}$ & Authigenic apatite & Authi Ca-P \\
\hline $\mathrm{III}_{\mathrm{b}}$ & $1 \mathrm{M} \mathrm{MgCl}_{2}(\mathrm{pH} 8)$ & $0.5 \mathrm{~h}$ & Washing step & \\
\hline IV & $1 \mathrm{MHCl}$ & $24 \mathrm{~h}$ & Detrital apatite & Detr-Pb \\
\hline V & $\begin{array}{l}\text { Combustion at } 550^{\circ} \mathrm{C} \\
1 \mathrm{M} \mathrm{HCl}\end{array}$ & $\begin{array}{l}2 \mathrm{~h} \\
24 \mathrm{~h}\end{array}$ & Organic $\mathrm{P}$ & Org-P \\
\hline
\end{tabular}

${ }^{a} \mathrm{Fe}(\mathrm{II})$ phosphates as vivianite can also dissolved in the citrate-dithionite-bicarbonate (CDB) solution, as shown by Dijkstra et al. (2016) and Nembrini et al. (1983).

$\mathrm{b}$ Authigenic Ca-P and detrital $\mathrm{P}$ are assumed to both represent $\mathrm{Ca}$ phosphates with different susceptibilities towards acid dissolution and are summed as Ca-P.

al. (1996), with the inclusion of the exchangeable P step. The extraction steps are summarized in Table 2. The P concentrations in the citrate-dithionite-bicarbonate (CDB) solutions were measured by ICP-OES. The $\mathrm{P}$ concentrations in the other extractants were measured colorimetrically by the molybdenum blue method (Strickland and Parsons, 1972). For holes $\mathrm{C}$ and $\mathrm{A}_{\mathrm{HR}}$, the total extracted $\mathrm{P}$ was almost similar to the total $\mathrm{P}$ concentrations as derived by total destruction ( $<15 \%$ difference). For hole A, the sum of all extracted elements for the sediments from hole A slightly underestimated the total $\mathrm{P}$ content (on average $18 \%$ lower). The relative standard deviations, as based on sample triplicates and in-house standards, were generally below $10 \%$. To avoid changes in $\mathrm{P}$ fractionation related to sample oxidation (Kraal et al., 2009; Kraal and Slomp, 2014), samples that were collected during the expedition and onshore sampling (holes $\mathrm{C}$ and $\mathrm{A}$ ) were not exposed to oxygen during sample preparation and the first six steps of the $\mathrm{P}$ extraction. The samples from hole $\mathrm{A}_{\mathrm{HR}}$ were exposed to oxygen for over a year before sample collection and were therefore not treated anoxically during the SEDEX. Trends with sediment depth were, however, similar between the different holes and sampling campaigns, suggesting no distinct changes in P fractionation due to sample oxidation.

Apart from the sequential P extractions, we investigated the $\mathrm{P}$ fractionation in a sediment sample from $11.67 \mathrm{mcd}$ (hole $\mathrm{C}$ ) with unfocused X-ray absorption near-edge structure (XANES) spectroscopy. The analysis was conducted in April 2015 at the ID21 beamline at the European Synchrotron Radiation Facility (ESRF) in Grenoble, France (see Salomé et al., 2013 for details on the beamline). Prior to analysis, the monochromator was calibrated against the first derivative of tricalcium phosphate $(2149.43 \mathrm{eV})$. The ground sediment was fixed between Kapton ${ }^{\circledR}$ tape and analyzed under vacuum with an unfocused beam in fluorescence mode at the P K edge (2130-2300 eV; room temperature). Background removal and normalization were performed using the ATHENA software package (Ravel and Newville, 2005). We applied a three-point smoothing on the mean spectrum (the number of individual spectra is 35) to reduce overall noise. All standards are described in Dijkstra et al. (2016).

\subsection{SEM-EDS of blue spherical aggregates}

While examining sediments with a light microscope, we observed blue spherical aggregates in sediments from $11.98 \mathrm{mcd}$ (hole $\mathrm{A}_{\mathrm{HR}}$ ). These aggregates were coated with carbon, mounted on an aluminum stub with carbon tape and investigated by scanning electron microscope energy dispersive spectroscopy (SEM-EDS; JCM 6000PLUS NeoScope Benchtop SEM). The imaging was conducted in backscatter mode with an acceleration voltage of $15 \mathrm{kV}$. We performed EDS in the $0-20 \mathrm{keV}$ energy range for elemental quantification of the aggregates (probe current: $1 \mathrm{nA}$; acquisition time: $50 \mathrm{~s}$ ). The SEM-EDS software was used to estimate the relative abundances in $\mathrm{mol} \%$ for the major elements (standardless ZAF procedure). Elements associated with salt particles and clays (i.e., $\mathrm{Na}$ and $\mathrm{K}$ ) were on average below $2 \mathrm{~mol} \%$ and were not included in the results.

\subsection{Vivianite sulfidization experiment}

We performed a sulfidization experiment to examine the stability of vivianite in the presence of sulfide. Various Pbearing minerals were synthesized by mixing a $0.2 \mathrm{M} \mathrm{Mohr}$ salt solution $\left(\left(\mathrm{NH}_{4}\right)_{2} \mathrm{Fe}\left(\mathrm{SO}_{4}\right)_{2} \cdot 6 \mathrm{H}_{2} \mathrm{O}\right)$ with a solution of $0.16 \mathrm{M}$ ammonium acetate and $0.47 \mathrm{M}$ disodium phosphate in a glovebox (1:1 volume ratio) following procedures described by Rouzies et al. (1993). We also added $0.6 \mathrm{M} \mathrm{MgCl}_{2}$ and $0.6 \mathrm{M} \mathrm{MnCl}_{2}$ solutions in various ratios to the Fe-P solution to synthesize minerals with varying $\mathrm{Fe}, \mathrm{Mg}$ and $\mathrm{Mn}$ 
Table 3. Key characteristics of the synthesized phosphate minerals with molar iron (Fe), magnesium $(\mathrm{Mg})$ and manganese (Mn) fractions in the precipitates relative to phosphorus (P). The mineralogy was investigated by X-ray diffraction (XRD) (Fig. 9a).

\begin{tabular}{llrrrrl}
\hline No. & Mineral phase & $\left(\mathrm{Fe}_{\text {tot }}+\mathrm{Mg}_{\text {tot }}+\mathrm{Mn}_{\text {tot }}\right) / \mathrm{P}_{\text {tot }}$ & $\mathrm{Fe}_{\text {tot }}$ & $\mathrm{Mg}_{\text {tot }}$ & $\mathrm{Mn}_{\text {tot }}$ & Color \\
\hline 1 & Vivianite & 1.49 & 1.40 & 0.09 & 0.00 & Dark blue \\
2 & Vivianite & 1.44 & 1.24 & 0.14 & 0.06 & Dark blue \\
3 & Vivianite & 1.44 & 0.99 & 0.14 & 0.31 & Blue \\
4 & Vivianite and struvite & 1.41 & 0.74 & 0.31 & 0.36 & Blue \\
5 & Vivianite and struvite & 1.34 & 0.81 & 0.52 & 0.01 & Light blue \\
\hline
\end{tabular}

concentrations. All chemical solutions were deoxygenated before mixing and prepared in sulfate-free artificial seawater with a salinity of 14 , which is equal to the porewater salinity at the P peak location in the sediments (Fig. 3). After 24h, the precipitates were filtered and washed twice with deoxygenated water and dried in the glovebox for 7 days. A small subsample (0.01-0.1 g) of each precipitate was destructed in hydrofluoric acid, nitric acid and perchloric acid for $24 \mathrm{~h}$. After evaporation of the acids, the residue was redissolved in $1 \mathrm{M}$ nitric acid and analyzed by ICP-OES for $\mathrm{P}, \mathrm{Fe}, \mathrm{Mn}$ and $\mathrm{Mg}$ concentrations (relative standard deviation was $11 \%$ on average, based on duplicates and triplicates). The mineralogy of the precipitates was determined by X-ray diffraction(XRD) using a Bruker D2 diffractometer with Cobalt K $\alpha$ radiation over a 5-85 $2 \theta$ range with a step size of $0.026^{\circ}$. Two precipitates ( 1 and 4 ) were also examined by SEM-EDS (see Sect. 2.6 for technical details).

We synthesized three vivianite minerals (precipitates 1-3) and two mixtures of vivianite and struvite $\left(\mathrm{MgNH}_{4} \mathrm{PO}_{4} \cdot 6 \mathrm{H}_{2} \mathrm{O}\right.$; precipitates 4 and 5) (Table 3). The $(\mathrm{Fe}+\mathrm{Mg}+\mathrm{Mn}) / \mathrm{P}$ ratio for the vivianite precipitates is between 1.44 and $1.49 \mathrm{~mol} \mathrm{~mol}^{-1}$ (Table 3) and thus close to the theoretical stoichiometric ratio of $1.5 \mathrm{~mol} \mathrm{~mol}^{-1}$ (Nriagu, 1972). The total fraction of $\mathrm{Mg}, \mathrm{Mn}, \mathrm{Fe}$ relative to total P ( $\mathrm{Mg}_{\text {tot }}, \mathrm{Mn}_{\mathrm{tot}}, \mathrm{Fe}_{\text {tot }}$; Table 3) can be used to estimate the relative contribution of vivianite and struvite to the mixed precipitates at the start of the experiment $\left(\mathrm{P}_{\text {stru }}\right.$ and $\left.\mathrm{P}_{\mathrm{viv}}\right)$. The elemental fractions in vivianite and struvite are expressed as

$$
\begin{aligned}
& \frac{\left(\mathrm{Mg}_{\text {viv }}+\mathrm{Mn}_{\text {viv }}+\mathrm{Fe}_{\text {viv }}\right)}{\mathrm{P}_{\text {viv }}}=1.5 \\
& \frac{\mathrm{Mg}_{\text {stru }}}{\mathrm{P}_{\text {stru }}}=1.0 .
\end{aligned}
$$

Equations (1)-(2) can be solved with the following assumptions: (1) $\mathrm{Fe}$ and $\mathrm{Mn}$ are only incorporated in vivianite (i.e., $\mathrm{Mn}_{\text {tot }}=\mathrm{Mn}_{\text {viv }}$ and $\mathrm{Fe}_{\text {tot }}=\mathrm{Fe}_{\text {viv }}$ ) and (2) the fraction of $\mathrm{Mg}$ in vivianite is $14 \%$ of the $\mathrm{P}$ fraction in vivianite, i.e., $\mathrm{Mg}_{\text {viv }}=$ $0.14 \mathrm{P}_{\text {viv }}$, in accordance with the $\mathrm{Mg} / \mathrm{P}$ ratio of vivianite precipitates 2 and 3 (Table 3). Rearranging terms leads to Eq. (3) with one unknown parameter $\left(\mathrm{P}_{\text {viv }}\right)$ :

$$
\frac{0.14 \mathrm{P}_{\mathrm{viv}}+\mathrm{Mn}_{\text {tot }}+\mathrm{Fe}_{\mathrm{tot}}}{\mathrm{P}_{\mathrm{viv}}}=1.5 \frac{\mathrm{Mg}_{\text {tot }}-0.14 \mathrm{P}_{\mathrm{viv}}}{1-\mathrm{P}_{\mathrm{viv}}} \text {. }
$$

Using Eq. (3), we estimated that $80 \%$ of $\mathrm{P}$ in precipitate 4 is incorporated in vivianite and $20 \%$ in struvite $\left(\mathrm{P}_{\text {stru }}=1-\right.$ $\left.\mathrm{P}_{\text {viv }}\right)$. Precipitate 5 is estimated to contain more struvite than precipitate 4 , with $42 \%$ of all $\mathrm{P}$ being present in struvite.

Small subsamples of the five precipitates $(\sim 5 \mathrm{mg})$ were inserted into $50 \mathrm{~mL}$ centrifuge tubes that contained the artificial seawater solution (salinity of 14) with 0 or $1000 \mu \mathrm{M}$ sulfide $(30-50 \mathrm{~mL}$ seawater, depending on the mass of the subsamples). The additional weight of the Eppendorf tubes due to replacement of air by argon in the argon-filled glovebox was subtracted from the sample masses. All experiments were performed in duplicate $(2 \times 2 \times 5$ samples in total). The samples were stored in aluminum bags filled with $\mathrm{N}_{2}$ gas and placed on a shaker. At eight time steps within $408 \mathrm{~h}$, the samples were centrifuged and the supernatant was sampled in the glovebox for sulfide measurements $(200 \mu \mathrm{L}$ in a $4.5 \% \mathrm{Zn}$ acetate solution) and $\mathrm{P}$ analysis ( $1 \mathrm{~mL}$ to $20 \mu \mathrm{L}$ $0.2 \mathrm{M} \mathrm{HCl})$. The sulfide concentrations in the zinc-acetate solutions were measured colorimetrically with a diamine solution ( $\mathrm{FeCl}_{3}$ and $\mathrm{N}, \mathrm{N}$-dimethyl-p-phenylenediamine sulfate) according to Cline (1969). The molybdenum blue method of Strickland and Parsons (1972) was used to measure P concentrations. The $\mathrm{P}$ concentrations were multiplied by the solution volume (corrected for volume loss due to sampling) and divided by the sample mass to calculate relative percentages of dissolved P. For three samples, the measured sulfide concentrations in tubes with precipitate 3 were much lower than observed for all other vivianite samples from the same time steps $(<35 \mu \mathrm{M}$ at $0.5,4$ and $24 \mathrm{~h})$. The low concentrations were attributed to a measurement error and excluded in Fig. 9.

\subsection{Reactive transport model}

\subsubsection{General description}

We developed a one-dimensional reactive transport model to investigate the temporal evolution of vivianite in the Bornholm Basin and its sensitivity to changes in salinity, primary productivity and bottom-water redox conditions. The model describes the temporal evolution of 27 species (Table 4) via a set of mass conservation equations that include physical transport as well as biogeochemical transformations. Their generic form for solids and solutes is, respectively, 
Table 4. Chemical species included in the diagenetic model.

\begin{tabular}{lll}
\hline Species & Notation & Type \\
\hline Organic carbon $^{\mathrm{a}}$ & $\mathrm{C}_{\mathrm{org}}^{\propto, \beta, \gamma}$ & Solid \\
Iron oxides $^{\mathrm{a}}$ & $\mathrm{Fe}(\mathrm{OH})_{3}^{\propto, \beta, \gamma}$ & Solid \\
Iron-oxide-bound phosphorus $^{\mathrm{a}}$ & $\mathrm{Fe}_{\mathrm{ox}} \mathrm{P}^{\propto, \beta, \gamma}$ & Adsorbed and co-precipitated \\
Iron monosulfide $^{\text {Pyrite }}$ & $\mathrm{FeS}$ & Solid \\
Siderite & $\mathrm{FeS}_{2}$ & Solid \\
Elemental sulfur & $\mathrm{FeCO}_{3}$ & Solid \\
Vivianite & $\mathrm{S}_{0}$ & Solid \\
Organic phosphorus & $\mathrm{Fe}_{3}\left(\mathrm{PO}_{4}\right)_{2}$ & Solid \\
Calcium-bound phosphorus (both apatite and detrital) $)$ & $\mathrm{Parg}_{\mathrm{Or}^{2}}$ & Solid \\
Chloride & $\mathrm{Cl}^{-}$ & Solid \\
Calcium & $\mathrm{Ca}^{2+}$ & Solute \\
Oxygen & $\mathrm{O}_{2}$ & Solute \\
Sulfate & $\mathrm{SO}_{4}^{2-}$ & Solute \\
Iron & $\mathrm{Fe}^{2+}$ & Solute \\
Hydrogen sulfide & Solute \\
Methane & $\sum \mathrm{H}_{2} \mathrm{~S}$ & Solute \\
Total ammonia & $\mathrm{CH}_{4}$ & Solute \\
Nitrate & $\sum \mathrm{NH}_{4}^{+}$ & Solute \\
Total phosphate & $\mathrm{NO}_{3}^{-}$ & Solute \\
Dissolved inorganic carbon & $\sum \mathrm{PO}_{4}^{3-}$ & Solute \\
\hline
\end{tabular}

a There are three types of species: reactive $(\alpha)$, less reactive $(\beta)$ and refractory $(\gamma){ }^{\mathrm{b}} \sum$ denotes that all species of an acid are included.

$\frac{\partial C_{\mathrm{s}}}{\partial t}=\frac{1}{(1-\phi)} \frac{\partial}{\partial x}\left(-v(1-\phi) C_{\mathrm{s}}\right)+\sum R_{\mathrm{s}}$

$\frac{\partial C_{\mathrm{p}}}{\partial t}=\frac{1}{\phi} \frac{\partial}{\partial x}\left(D^{\prime} \phi \frac{\partial C_{\mathrm{p}}}{\partial x}-u \phi C_{\mathrm{p}}\right)+\sum R_{\mathrm{p}}$,

where $C_{\mathrm{s}}$ is the concentration of the solid species $\left(\mathrm{mol} \mathrm{cm}{ }^{-3}\right.$; mass per unit volume of solids), $C_{\mathrm{p}}$ is the concentration of the solute $\left(\mathrm{mol} \mathrm{cm}^{-3}\right.$; mass per unit volume of porewater), $t$ is time (year), $\phi$ is sediment porosity, $x$ is distance from the sediment-water interface $(\mathrm{cm}), D^{\prime}$ is the respective molecular diffusion coefficient in the sediment $\left(D_{\mathrm{m}}\right.$; $\left.\mathrm{cm}^{2} \mathrm{yr}^{-1}\right)$ at in situ conditions and corrected for tortuosity ( $\theta^{2}$; Table S2; Boudreau, 1996), $v$ and $u$ are the advective velocities $\left(\mathrm{cm} \mathrm{yr}^{-1}\right)$ of the solid phase and porewater, respectively, and $\sum R_{\mathrm{S}}$ and $\sum R_{\mathrm{p}}$ are the net reaction rates $\left(\mathrm{mol} \mathrm{cm} \mathrm{cm}^{-3} \mathrm{yr}^{-1}\right)$ per unit volume of solids and porewater, respectively. Note that bioturbation and biodiffusion are not included in Eqs. (4)-(5) since the Bornholm Basin is assumed to have been hypoxic during the main period of interest (7500 years BP-present), thus implying limited benthic faunal activity. Porosity was described by an exponentially decreasing function of the form

$\phi(x)=\phi_{\infty}\left(\phi_{0}-\phi_{\infty}\right) \exp \left(-\frac{x}{\gamma}\right)$
The parameters $\phi_{\text {inf }}$ (porosity at depth), $\phi_{0}$ (porosity at the sediment-water interface) and $\gamma$ (porosity $e$-folding distance; $\mathrm{cm}$ ) were fit to the observed porosity profile (Fig. S1; Table S3), which was assumed to be constant over the simulation time. As a result, we calculated advective velocities assuming steady-state compaction (Boudreau, 1997; Meysman et al., 2005).

Biogeochemical reactions and their corresponding rate laws are given in Tables 5 and 6, respectively. Rate constants and other reaction parameters were mostly taken from the literature or, in the case that no fit to the data could be obtained, constrained using the model (Table 7). Both Fe oxides and organic matter were divided into highly reactive $(\alpha)$, less reactive $(\beta)$ and inert $(\gamma)$ phases. In comparison with $\mathrm{Fe}(\mathrm{OH})_{3}^{\alpha}$, the $\beta$ phase is not used by organoclastic Fe reduction. This assumption is made to ensure that part of the reactive $\mathrm{Fe}$ oxides are buried even under higher organic matter loading. The phosphate minerals apatite $\left(\mathrm{Ca}_{5}\left(\mathrm{PO}_{4}\right)_{3} \mathrm{OH}\right)$ and vivianite were included in the model as sinks of porewater $\mathrm{PO}_{4}^{3-}$. Their formation was described by second-order kinetics (Egger et al., 2016; Rooze et al., 2016). In line with Egger et al. (2016), vivianite was subject to dissolution under sulfidic (euxinic) porewater conditions. Siderite $\left(\mathrm{FeCO}_{3}\right)$ formation and dissolution were described similarly to vivianite kinetics. The model additionally included linear adsorption of $\mathrm{NH}_{4}^{+}$ (Mackin and Aller, 1984; Soetaert and Herman, 2009). 
Table 5. Reaction pathways and associated stoichiometries implemented in the diagenetic model.

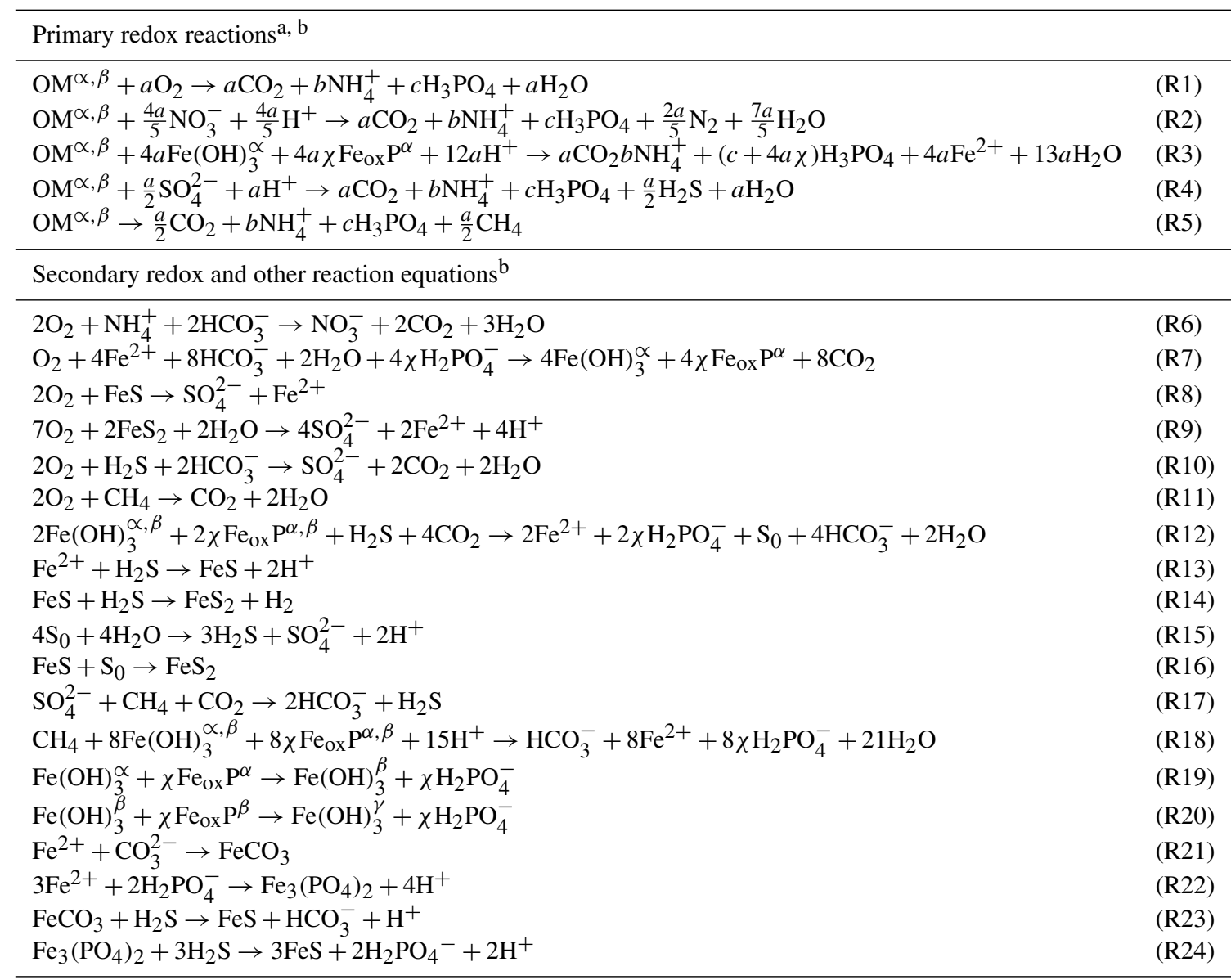

a Organic matter $\left(\mathrm{OM}^{\alpha, \beta}\right)$ is of the form $\left(\mathrm{CH}_{2} \mathrm{O}\right)_{a}\left(\mathrm{NH}_{4}^{+}\right)_{b}\left(\mathrm{H}_{3} \mathrm{PO}_{4}\right)_{c}$, with " $a$ " $=1, " b$ " =16/106 and " $c$ " $=1 / 106$. ${ }^{\mathrm{b}} \chi$ refers to the $\mathrm{P}$ : Fe ratio of $\mathrm{Fe}(\mathrm{OH})_{3}^{\alpha, \beta, \gamma}$. R6 is nitrification; $\mathrm{R} 7$ is $\mathrm{Fe}(\mathrm{OH})_{3}$ formation; $\mathrm{R} 8$ is $\mathrm{FeS}$ oxidation; $\mathrm{R} 9$ is $\mathrm{FeS}_{2}$ oxidation; $\mathrm{R} 10$ is $\mathrm{H}_{2} \mathrm{~S}$ oxidation; $\mathrm{R} 11$ is aerobic $\mathrm{CH}_{4}$ oxidation; $\mathrm{R} 12$ is $\mathrm{Fe}(\mathrm{OH})_{3}$ reduction by $\mathrm{H}_{2} \mathrm{~S} ; \mathrm{R} 13$ is FeS formation; $\mathrm{R} 14$ is pyrite formation $\left(\mathrm{H}_{2} \mathrm{~S}\right.$ pathway); R15 is $\mathrm{S}_{0}$ disproportionation; R16 is pyrite formation (polysulfide pathway); $\mathrm{R} 17$ is anaerobic oxidation of methane with $\mathrm{SO}_{4}^{2-}\left(\mathrm{SO}_{4}-\mathrm{AOM}\right)$; $\mathrm{R} 18$ is Fe-AOM; $\mathrm{R} 19$ is conversion (i.e., crystallization) from $\alpha$ to $\beta$ phase; $\mathrm{R} 20$ is crystallization from $\beta$ to $\gamma$ phase; $\mathrm{R} 21$ is siderite precipitation; R22 is vivianite formation; R23 is siderite dissolution with $\mathrm{H}_{2} \mathrm{~S} ; \mathrm{R} 24$ is vivianite dissolution with $\mathrm{H}_{2} \mathrm{~S}$.

Boundary conditions at the sediment-water interface were prescribed as concentrations for the solutes and fluxes for the solids (Table S4). We applied a zero-gradient boundary condition to all species at the lower boundary. The model code was written in $\mathrm{R}$ (version 3.4.0) using the marelac package (Soetaert et al., 2010a) for chemical and physical constants and the calculation of diffusion coefficients. Physical transport was calculated with the ReacTran package (Soetaert and Meysman, 2012). The depth domain, which describes the upper $50 \mathrm{~m}$ of the sediment, was discretized into 450 layers with highest resolution at the top and between 9 and $12 \mathrm{~m}$. The set of equations obtained upon discretization of the mass conservation equations was solved with the lsoda ordinary differential equation solver (Hindmarsh, 1983; Petzold, 1983) that is included in the deSolve package (Soetaert et al., 2010b).

\subsubsection{Reconstructing the diagenetic history of the Bornholm Basin}

The model was used to describe the diagenetic history of the Bornholm Basin over the past 25000 years, thereby assuming no changes in environmental conditions or fluxes before 20000 years BP. A spinup period of 55000 years was used to ensure no effect of the initial conditions on the model solution in the major zone of interest, i.e., around the lake-marine transition. The sedimentation rate for the marine phase was estimated at $1.6 \mathrm{~mm} \mathrm{yr}^{-1}$ and kept constant for the entire simulation period, as we have no information on the sedimentation rate in the lake phase. This rate corresponds to a lake-marine transition at $\sim 7.5 \mathrm{kyr}$ as estimated by Zillen et al. (2008).

The flux of organic matter (OM) entering the sediment was fit to the observed $\mathrm{C}_{\text {org }}$ profile, thereby assuming that in the marine phase the ratio of the various organic mat- 
Table 6. Reaction equations implemented in the model.

\begin{tabular}{|c|c|}
\hline \multicolumn{2}{|l|}{ Primary redox reaction equations } \\
\hline $\mathrm{R} 1=k_{\propto, \beta} \mathrm{OM}^{\propto, \beta}\left(\frac{\left[\mathrm{O}_{2}\right]}{\kappa_{\mathrm{O}_{2}+\left[\mathrm{O}_{2}\right]}}\right)$ & (E1) \\
\hline $\mathrm{R} 2=k_{\propto, \beta} \mathrm{OM}^{\alpha, \beta}\left(\frac{\left[\mathrm{NO}_{3}^{-}\right]}{K_{\mathrm{NO}_{3}^{-}+\left[\mathrm{NO}_{3}^{-}\right]}}\right)\left(\frac{K_{\mathrm{O}_{2}}}{K_{\mathrm{O}_{2}+\left[\mathrm{O}_{2}\right]}}\right)$ & (E2) \\
\hline $\mathrm{R} 3=k_{\alpha, \beta} \mathrm{OM}^{\alpha, \beta}\left(\frac{\left[\mathrm{Fe}(\mathrm{OH})_{3}^{\alpha}\right]}{K_{\mathrm{Fe}(\mathrm{OH})_{3}^{\alpha}+\left[\mathrm{Fe}(\mathrm{OH})_{3}^{\alpha}\right]}^{\alpha}}\right)\left(\frac{K_{\mathrm{NO}_{3}^{-}}}{K_{\mathrm{NO}_{3}^{-}+\left[\mathrm{NO}_{3}^{-}\right]}}\right)\left(\frac{K_{\mathrm{O}_{2}}}{K_{\mathrm{O}_{2}}+\left[\mathrm{O}_{2}\right]}\right)$ & (E3) \\
\hline 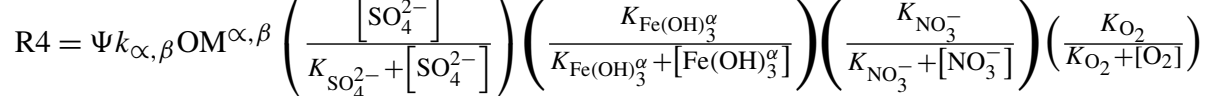 & (E4) \\
\hline 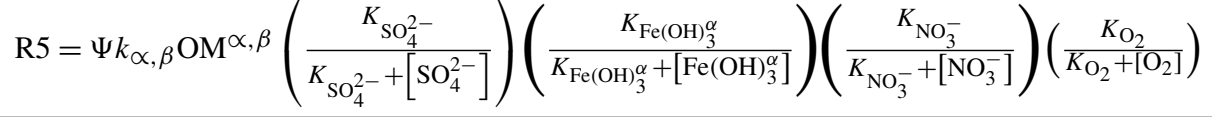 & (E5) \\
\hline \multicolumn{2}{|l|}{ Secondary redox and other reaction equations } \\
\hline $\mathrm{R} 6=k_{1}\left[\mathrm{O}_{2}\right]\left[\sum \mathrm{NH}_{4}^{+}\right]$ & (E6) \\
\hline $\mathrm{R} 7=k_{2}\left[\mathrm{O}_{2}\right]\left[\mathrm{Fe}^{2+}\right]$ & (E7) \\
\hline $\mathrm{R} 8=k_{3}\left[\mathrm{O}_{2}\right][\mathrm{FeS}]$ & (E8) \\
\hline $\mathrm{R} 9=k_{4}\left[\mathrm{O}_{2}\right]\left[\mathrm{FeS}_{2}\right]$ & (E9) \\
\hline $\mathrm{R} 10=k_{5}\left[\mathrm{O}_{2}\right]\left[\sum \mathrm{H}_{2} \mathrm{~S}\right]$ & (E10) \\
\hline $\mathrm{R} 11=k_{6}\left[\mathrm{O}_{2}\right]\left[\mathrm{CH}_{4}\right]$ & (E11) \\
\hline $\mathrm{R} 12=k_{7}\left[\mathrm{Fe}(\mathrm{OH})_{3}^{\alpha, \beta}\right]\left[\sum \mathrm{H}_{2} \mathrm{~S}\right]$ & (E12) \\
\hline $\mathrm{R} 13=k_{8}\left[\mathrm{Fe}^{2+}\right]\left[\sum \mathrm{H}_{2} \mathrm{~S}\right]$ & (E13) \\
\hline $\mathrm{R} 14=k_{9}[\mathrm{FeS}]\left[\sum \mathrm{H}_{2} \mathrm{~S}\right]$ & (E14) \\
\hline $\mathrm{R} 15=k_{10}\left[\mathrm{~S}_{0}\right]$ & (E15) \\
\hline $\mathrm{R} 16=k_{11}[\mathrm{FeS}]\left[\mathrm{S}_{0}\right]$ & (E16) \\
\hline $\mathrm{R} 17=k_{12}\left[\mathrm{SO}_{4}^{2-}\right]\left[\mathrm{CH}_{4}\right]$ & (E17) \\
\hline $\begin{array}{l}\mathrm{R} 18=k_{13}\left[\mathrm{Fe}(\mathrm{OH})_{3}^{\alpha, \beta}\right]\left[\mathrm{CH}_{4}\right] \\
\mathrm{R} 19=k_{14}\left[\mathrm{Fe}(\mathrm{OH})_{3}^{\alpha}\right]\end{array}$ & $\begin{array}{l}(\mathrm{E} 18) \\
(\mathrm{E} 19)\end{array}$ \\
\hline $\mathrm{R} 20=k_{15}\left[\mathrm{Fe}(\mathrm{OH})_{3}^{\beta}\right]$ & (E20) \\
\hline $\mathrm{R} 21=k_{16}\left[\mathrm{Fe}^{2+}\right][\mathrm{DIC}]$ & $(\mathrm{E} 21)$ \\
\hline $\mathrm{R} 22=k_{17}\left[\mathrm{Fe}^{2+}\right]\left[\sum \mathrm{PO}_{4}^{3-}\right]$ & $(\mathrm{E} 22)$ \\
\hline $\mathrm{R} 23=k_{18}\left[\mathrm{FeCO}_{3}\right]\left[\sum \mathrm{H}_{2} \mathrm{~S}\right]$ & (E23) \\
\hline $\mathrm{R} 24=k_{19}\left[\mathrm{Fe}_{3}\left(\mathrm{PO}_{4}\right)_{2}\right]\left[\sum \mathrm{H}_{2} \mathrm{~S}\right]$ & (E24) \\
\hline
\end{tabular}

ter fractions obeyed the multi-G model as determined for fresh planktonic material, i.e., $50 \%$ highly reactive, $16 \%$ less reactive and $34 \%$ refractory organic matter (Westrich and Berner, 1984; Fig. 2). Similarly, we varied bottom-water salinity conditions such that a best fit to the observed porewater $\mathrm{Cl}^{-}$profile was obtained. Iron oxides enter the sediment in a temporally varying ratio of its most reactive $\left(\mathrm{Fe}(\mathrm{OH})_{3}^{\alpha}\right)$, less reactive $\left(\mathrm{Fe}(\mathrm{OH})_{3}^{\beta}\right.$ ) and crystalline $\left(\mathrm{Fe}(\mathrm{OH})_{3}^{\gamma}\right)$ forms. We assumed that all $\mathrm{Fe}$ oxides deposited before 20000 years $\mathrm{BP}$ were crystalline. The Fe loading was furthermore adjusted to fit the observed sedimentary profiles of Fe oxide and S. During the onset of the Holocene Thermal Maximum (7500-4500 years BP), an interval of high productivity and widespread anoxia, we assumed that part of the $\mathrm{Fe}$ oxides had been transformed to pyrite before settling onto the sediment surface. After the termination of bottom-water euxinia, which we set at 7000 years BP, bottom waters were assumed to remain anoxic. Even though periods of oxygenation have occurred since then (Jensen et al., 2017; Zillén et al., 2008), the average bottom-water oxygen concentration was likely low.

\section{Results}

\subsection{Porewater data}

Salinity and $\mathrm{Mg}^{2+}$ concentrations are high in the brackishmarine sediments and gradually decrease with sediment depth (Fig. 3). The brackish-marine deposits are also characterized by high porewater alkalinity and DIC, as well as high $\mathrm{NH}_{4}^{+}$and $\mathrm{PO}_{4}$ concentrations, which are all key products of organic matter decomposition. While alkalinity, DIC and $\mathrm{NH}_{4}^{+}$gradually decrease with sediment depth, a sharper decline across the lake-marine transition is ob- 
Table 7. Reaction parameters used in the diagenetic model.

\begin{tabular}{|c|c|c|c|c|c|}
\hline Parameter & Symbol & Value & Units & Source & $\begin{array}{l}\text { Range given by source } \\
\text { (if applicable, value } \\
\text { given by source) }\end{array}$ \\
\hline Decay constant for $\mathrm{C}_{\mathrm{org}}^{\alpha}$ & $k_{\alpha}$ & 0.4 & $\mathrm{yr}^{-1}$ & $a, b, c$ & $0.05-0.07^{\mathrm{a}}, 1.62^{\mathrm{a}, \mathrm{b}, \mathrm{c}}$ \\
\hline Decay constant for $C_{\text {org }}^{\beta}$ & $k_{\beta}$ & 0.02 & $\mathrm{yr}^{-1}$ & $\mathrm{a}, \mathrm{b}$ & $0.00070-0.0086^{\mathrm{a}, \mathrm{b}}$ \\
\hline Limiting concentration of $\mathrm{O}_{2}$ & $K_{\mathrm{O}_{2}}$ & 20 & $\mu \mathrm{mol} \mathrm{L}-1$ & $\mathrm{~d}$ & $1-30(20)$ \\
\hline Limiting concentration of $\mathrm{NO}_{3}^{-}$ & $K_{\mathrm{NO}_{3}^{-}}$ & 4 & $\mu \mathrm{mol} \mathrm{L}^{-1}$ & $\mathrm{~d}$ & $4-80(2)$ \\
\hline Limiting concentration of $\mathrm{Fe}(\mathrm{OH})_{3}$ & $K_{\mathrm{Fe}(\mathrm{OH})_{3}}$ & 65 & $\mu \mathrm{mol} \mathrm{g}-1$ & d & $65-100(65,100)$ \\
\hline Limiting concentration of $\mathrm{SO}_{4}^{2-}$ & $K_{\mathrm{SO}_{4}^{2-}}$ & 1.6 & $\mathrm{mmol} \mathrm{L}^{-1}$ & d & 1.6 \\
\hline $\begin{array}{l}\mathrm{C}_{\text {org }}: \mathrm{P}_{\text {org }} \text { acceleration factor for } \mathrm{SO}_{4}^{2-} \\
\text { reduction and methanogenesis }\end{array}$ & $\eta$ & 10 & - & $\mathrm{e}$ & 30 \\
\hline Attenuation factor for (E4) and (E5) & $\Psi$ & 0.00157 & - & $\mathrm{b}$ & 0.00157 \\
\hline Rate constant for reaction (E6) & $k_{1}$ & 10000 & $\mathrm{mmol}^{-1} \mathrm{~L} \mathrm{yr}^{-1}$ & $\mathrm{~d}$ & $\approx 10000(5000)$ \\
\hline Rate constant for reaction (E7) & $k_{2}$ & 140000 & $\mathrm{mmol}^{-1} \mathrm{~L} \mathrm{yr}^{-1}$ & $\mathrm{~d}$ & 140000 \\
\hline Rate constant for reaction (E8) & $k_{3}$ & 300 & $\mathrm{mmol}^{-1} \mathrm{~L} \mathrm{yr}^{-1}$ & $\mathrm{~d}$ & 300 \\
\hline Rate constant for reaction (E9) & $k_{4}$ & 1 & $\mathrm{mmol}^{-1} \mathrm{~L} \mathrm{yr}^{-1}$ & $\mathrm{~d}$ & 1 \\
\hline Rate constant for reaction (E10) & $k_{5}$ & 160 & $\mathrm{mmol}^{-1} \mathrm{~L} \mathrm{yr}^{-1}$ & $\mathrm{~d}$ & $\geq 160(160)$ \\
\hline Rate constant for reaction (E11) & $k_{6}$ & 10000000 & $\mathrm{mmol}^{-1} \mathrm{~L} \mathrm{yr}^{-1}$ & $\mathrm{~d}$ & 10000000 \\
\hline Rate constant for reaction (E12) & $k_{7}$ & 0.4 & $\mathrm{mmol}^{-1} \mathrm{~L} \mathrm{yr}^{-1}$ & f & 0.4 \\
\hline Rate constant for reaction (E13) & $k_{8}$ & 1 & $\mathrm{mmol}^{-1} \mathrm{~L} \mathrm{yr}^{-1}$ & $b, f$ & 100 \\
\hline Rate constant for reaction (E14) & $k_{9}$ & 0.000315 & $\mathrm{mmol}^{-1} \mathrm{~L} \mathrm{yr}^{-1}$ & g & 0.0003 \\
\hline Rate constant for reaction (E15) & $k_{10}$ & 3 & $\mathrm{yr}^{-1}$ & $\mathrm{~h}$ & 3 \\
\hline Rate constant for reaction (E16) & $k_{11}$ & 7 & $\mathrm{mmol}^{-1} \mathrm{~L} \mathrm{yr}^{-1}$ & $b, f$ & 7 \\
\hline Rate constant for reaction (E17) & $k_{12}$ & 0.01 & $\mathrm{mmol}^{-1} \mathrm{~L} \mathrm{yr}^{-1}$ & $\mathrm{e}$ & 0.01 \\
\hline Rate constant for reaction (E18) & $k_{13}$ & $1.23 \times 10^{-6}$ & $\mathrm{mmol}^{-1} \mathrm{~L} \mathrm{yr}^{-1}$ & $\mathrm{~g}, \mathrm{i}$ & $1.6 \times 10^{-7 \mathrm{~g}}, 4.6 \times 10^{-7 \mathrm{i}}$ \\
\hline Rate constant for reaction (E19) & $k_{14}$ & 0.6 & $\mathrm{yr}^{-1}$ & $\mathrm{~h}$ & 0.6 \\
\hline Rate constant for reaction (E20) & $k_{15}$ & 0.000013 & $\mathrm{yr}^{-1}$ & $\mathrm{~g}$ & 0.000013 \\
\hline Rate constant for reaction (E21) & $k_{16}$ & 0.0005 & $\mathrm{mmol}^{-1} \mathrm{~L} \mathrm{yr}^{-1}$ & $\begin{array}{l}s \\
g\end{array}$ & 0.0027 \\
\hline Rate constant for reaction (E22) & $k_{17}$ & 0.025 & $\mathrm{mmol}^{-1} \mathrm{~L} \mathrm{yr}^{-1}$ & $\mathrm{~g}$ & 0.052 \\
\hline Rate constant for reaction (E23) & $k_{18}$ & 0.000005 & $\mathrm{mmol}^{-1} \mathrm{~L} \mathrm{yr}^{-1}$ & - & Model constrained \\
\hline Rate constant for reaction (E24) & $k_{19}$ & 0.025 & $\mathrm{mmol}^{-1} \mathrm{~L} \mathrm{yr}^{-1}$ & - & Model constrained \\
\hline Linear adsorption coefficient for $\mathrm{NH}_{4}^{+}$ & $K_{\mathrm{NH}_{4}}$ & 1.3 & - & $\mathrm{j}$ & 1.3 \\
\hline
\end{tabular}

served for $\mathrm{PO}_{4}$. The porewaters below $13 \mathrm{mcd}$ contain less than $0.15 \mathrm{mMPO}_{4}$. In all sediments, porewater $\mathrm{Ca}^{2+}$ concentrations are above $5 \mathrm{mM}$. Porewater $\mathrm{Fe}^{2+}$ concentrations vary strongly with low values in the brackish-marine sediments $(<0.1 \mathrm{mM})$ and high values in the Ancylus Lake sediments just below the lake-marine transition $(>0.8 \mathrm{mM})$. The porewaters in sediments around the lake-marine transition are high in $\mathrm{Mn}^{2+}(>0.2 \mathrm{mM})$, and porewater sulfide is only detected in the upper $5 \mathrm{~m}$ of the sediment $(<3 \mathrm{mM})$. Porewater $\mathrm{SO}_{4}^{2-}$ is high at the sediment-water interface $(14 \mathrm{mM})$ and sharply declines with sediment depth to values below $1 \mathrm{mM}$ in the deeper sediments $(<2 \mathrm{~m}$ sediment depth). Dissolved $\mathrm{CH}_{4}$ shows high concentrations of $>11 \mathrm{mM}$ in the porewaters of the brackish-marine sediments and decreases to $<2 \mathrm{mM}$ below $30 \mathrm{mcd}$.

\subsection{Organic carbon and total elemental concentrations}

The brackish-marine sediments are more organic rich than the deeper lake sediments ( $>3 \mathrm{wt} \%$ versus $\sim 0.5 \mathrm{wt} \%$; Fig. 4). Sedimentary Mo, $\mathrm{Mn}$ and $\mathrm{S}$ concentrations are highest at the lake-marine transition $(0.6,356$ and $1000 \mu \mathrm{mol} \mathrm{g}^{-1}$, respectively) and generally elevated in the brackish-marine sediments when compared to the Ancylus Lake deposits. Note that the lake sediments at or just below the lake-marine transition have elevated total $\mathrm{S}$ contents and sedimentary $\mathrm{Fe} / \mathrm{Al}$ ratios above $0.7 \mathrm{wt} \%$ wt $\%^{-1}$. We further observe a minimum in sedimentary $\mathrm{Al}, \mathrm{Mg}$ and $\mathrm{P}$ concentrations between 9.5 and $11.5 \mathrm{mcd}$, and a $\mathrm{P}$ enrichment of $\sim 60 \mu \mathrm{mol} \mathrm{g}^{-1}$ at $12 \mathrm{mcd}$. Total $\mathrm{Ca}$ is elevated in the lake sediments. The trend in $\mathrm{C}_{\mathrm{org}} / \mathrm{P}$ ratios generally follows the $\mathrm{C}_{\text {org }}$ trend with highest $\mathrm{C}_{\text {org }} / \mathrm{P}$ ratios $\left(>75 \mathrm{~mol} \mathrm{~mol}^{-1}\right)$ in the brackish-marine deposits. 

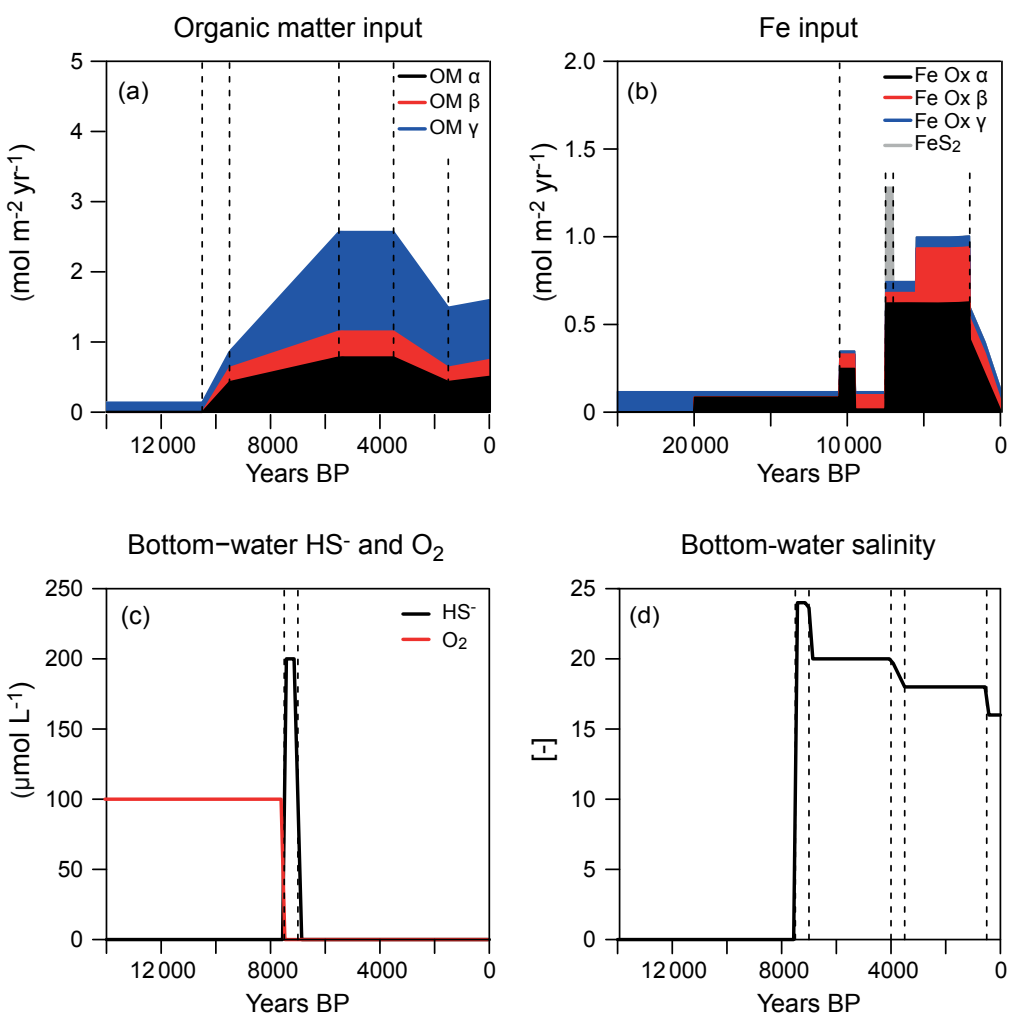

Figure 2. Model scenario of organic matter (OM) input (a), Fe input (b), bottom-water $\mathrm{HS}^{-}$and $\mathrm{O}_{2}$ concentrations (c), and bottom-water salinity (d). Both Fe oxides and organic matter were divided into highly reactive $(\alpha)$, less reactive $(\beta)$ and inert $(\gamma)$ phases. Note the different timescale for panel (b). Inputs and bottom-water concentrations were kept constant before the plotted time interval.

\subsection{Sulfur, iron and phosphorus speciation (including P XANES)}

The brackish-marine deposits contain on average 3 and $200 \mu \mathrm{molFeS} \mathrm{g}^{-1}$, whereas the lake sediments below $11 \mathrm{mcd}$ are low in both $\mathrm{FeS}$ and $\mathrm{FeS}_{2}(<1$ and $<25 \mu \mathrm{mol} \mathrm{g}{ }^{-1}$, respectively; Fig. 5). The highest concentrations of $\mathrm{FeS}$ and $\mathrm{FeS}_{2}$ are observed just below the lakemarine transition at $10.3 \mathrm{mcd}\left(10\right.$ and $300 \mu \mathrm{mol} \mathrm{g}^{-1}$, respectively). The brackish-marine sediments generally contain less $\mathrm{Fe}$ carbonates and $\mathrm{Fe}$ oxides than the lake sediments. Magnetite is a minor Fe phase throughout the record $\left(<50 \mu \mathrm{mol} \mathrm{g}^{-1}\right)$.

Exchangeable $\mathrm{P}$ is only a minor $\mathrm{P}$ fraction in the Bornholm Basin sediments $(<5 \%$ of total $\mathrm{P}$ at each sediment depth; Fig. 6). Organic $P$ is highest in the brackish-marine deposits and decreases to values of $<3 \mu \mathrm{mol} \mathrm{g}^{-1}$ at depth in the lake sediments. Ca-P is a major $\mathrm{P}$ phase throughout the sediment record, with lowest values in sediments just below the lakemarine transition. There are distinct peaks in sedimentary Fe-bound $\mathrm{P}$, and to a lesser degree in exchangeable $\mathrm{P}$, between 11.5 and $12 \mathrm{mcd}$. Maxima in Fe-bound $\mathrm{P}$ are located at $11.5 \mathrm{mcd}$ for hole $\mathrm{A}, 11.67 \mathrm{mcd}$ for hole $\mathrm{C}$ and $11.90 \mathrm{mcd}$ for hole $\mathrm{A}_{\mathrm{HR}}$. At these depths, Fe-bound $\mathrm{P}$ accounts for up to $63 \%$ of the total sedimentary P pool.
Bulk P XANES spectroscopy was performed on sediments from $11.67 \mathrm{mcd}$ (hole $\mathrm{C}$ ) for a more detailed investigation of the sedimentary P fractionation (Fig. 7). The results do not provide evidence for the presence of vivianite in the bulk sediments as the characteristic post-edge oscillations of vivianite are not observed in the sediment sample (see Fig. 7 for positions of XANES features). In addition, the position of the main peak (i.e., white line) of the bulk sediment is slightly shifted to higher energies compared to the white line of vivianite (difference: $0.1-0.2 \mathrm{eV}$ ). The spectrum of the sediment sample also does not resemble the almost featureless spectra of rhodochrosite-P and hureaulite either. Instead, the $\mathrm{P}$ XANES spectrum is most comparable to the P XANES spectrum of fluorapatite with a shoulder feature and postedge oscillations at similar energies $(2163.5$ and $2170 \mathrm{eV})$. Linear combination fitting of the bulk sediments was not possible due to the high amplitude of the white line caused by a strong self-adsorption effect.

\subsection{Examination of blue aggregates with SEM-EDS}

The blue spherical aggregates from $11.98 \mathrm{mcd}$ (hole $\mathrm{A}_{\mathrm{HR}}$ ) are approximately $400 \mu \mathrm{m}$ in size (Fig. 8). Elemental quantification of the aggregate surfaces with SEM-EDS suggests that the aggregates are enriched in Fe (between 13 to 

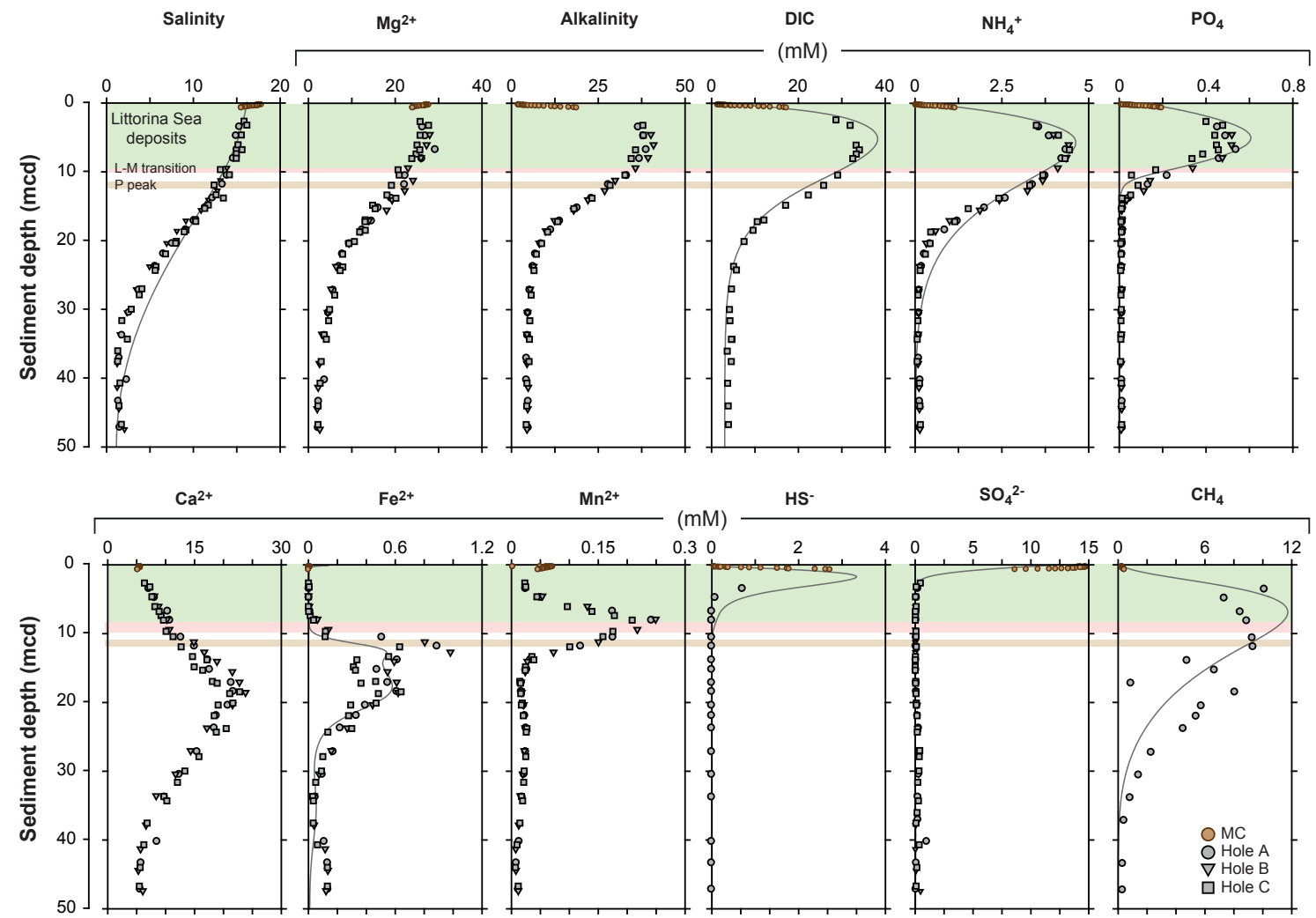

Figure 3. Porewater trends with sediment depth for station M0065 (holes A-C), including porewater data of the multicore from the same location (MC). Grey lines show profiles derived from the diagenetic model. The lake-marine (L-M) transition from Ancylus Lake sediments to the brackish-marine Littorina Sea sediments is indicated in pink (brackish-marine sediments in green). The depth at which a large $\mathrm{P}$ enrichment is observed in the sediments $\left(>50 \mu \mathrm{mol} \mathrm{g} \mathrm{g}^{-1}\right)$ is shaded in brown (P peak).

$83 \mathrm{~mol} \%)$. Other major elements are $\mathrm{P}(0.2-17.4 \mathrm{~mol} \%)$ and $\mathrm{Mn}(0.8-10.2 \mathrm{~mol} \%)$. We also detected some $\mathrm{Mg}$ on the surfaces of both aggregates $(0.8-8.2 \mathrm{~mol} \%)$. The enrichments in $\mathrm{Si}$ and $\mathrm{Al}$ likely reflect clay particles that are attached to the aggregates.

\subsection{Sulfidization experiment}

Within 17 days $(408 \mathrm{~h})$, most of the three vivianite precipitates had dissolved in the seawater solution that initially contained $1000 \mu \mathrm{M}$ sulfide (> 75\%; Fig. 9b). Almost no vivianite was dissolved in the sulfide-free seawater (generally $<10 \%$ of all P). The mixed vivianite-struvite precipitates show a different trend with time compared to the pure vivianite minerals (Fig. 9c). Only $25 \%$ of all $\mathrm{P}$ from precipitate 4 was dissolved in the sulfide-rich seawater solution. The percentage of dissolved $\mathrm{P}$ from precipitate 5 varied widely among the duplicate samples resulting in large standard deviations (error bars). In contrast to the pure vivianite samples, also some $\mathrm{P}$ from the vivianite-struvite precipitates dissolved in the seawater solutions that did not contain sulfide. The gradual decrease in sulfide contents with time in all samples (Fig. 9d and e) is assumed to be the result of the escape of sulfide from the solutions during sampling. Precipitates 1 and 4 were also examined by SEM-EDS before the start of the experiment (Fig. 10). Precipitate 1 generally consisted of $\sim 5 \mu \mathrm{m}$ crystals that contain $\mathrm{P}, \mathrm{Fe}$ and $\mathrm{Mg}$. Precipitate 4 consisted of a mixture of crystals rich in $\mathrm{P}, \mathrm{Fe}, \mathrm{Mn}$ and $\mathrm{Mg}$, and irregular-shaped precipitates that contain both $\mathrm{Mg}$ and $\mathrm{P}$.

\subsection{Model fits and transient evolution of solutes and particulates}

The reactive transport model reproduces the trends in all key porewater and solid phase profiles, including the observed enrichment in $\mathrm{P}$ at $\sim 11.5 \mathrm{mcd}$ (Figs. 3-6). Presentday rates of processes as calculated in the model are given in the Supplement. The vast majority of $\mathrm{P}$ in this peak is present as vivianite (Fig. 6). The time-depth profiles of DIC and $\mathrm{C}_{\text {org }} / \mathrm{P}_{\text {tot }}$ confirm that their temporal evolutions mainly result from the imposed increase in organic matter loading (Fig. 11). The pattern of $\mathrm{PO}_{4}$ does not follow that of DIC and indicates removal processes acting both in the surface layer as well as deeper in the sediment through the whole marine phase. The enhanced Fe loading concurring with the transition from freshwater to brackish-marine conditions in- 


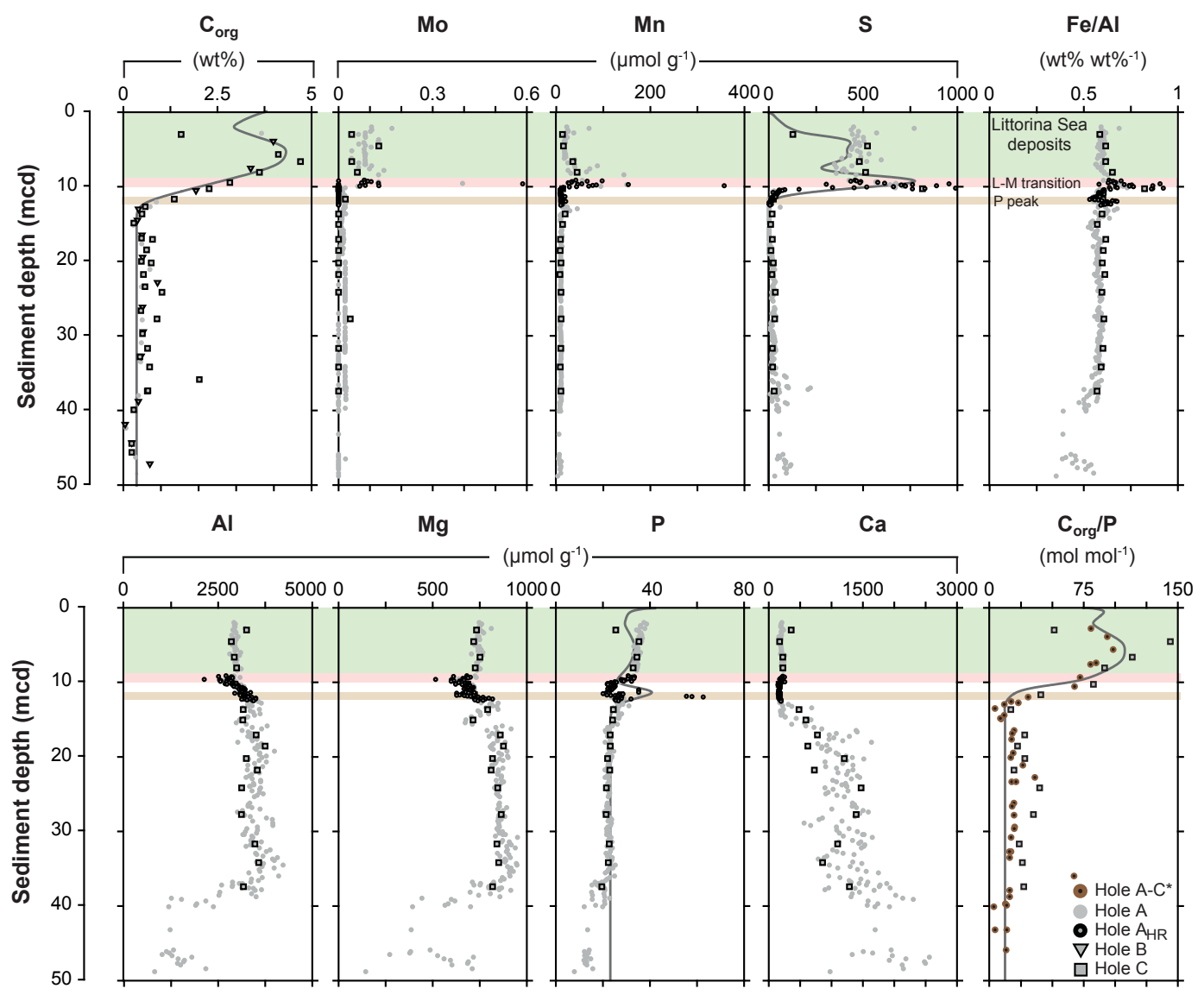

Figure 4. Key elements at station M0065 with sediment depth (solid grey lines: model outputs). More details on the colored areas can be found in the legend of Fig. 3. Hole $\mathrm{A}_{\mathrm{HR}}$ samples were taken from hole A cores more than 1 year after storage. ${ }^{*}$ The $\mathrm{C}_{\mathrm{org}} / \mathrm{P}$ ratios were calculated using $\mathrm{C}_{\text {org }}$ contents and estimated values of total $\mathrm{P}$ by interpolation between the nearest samples.

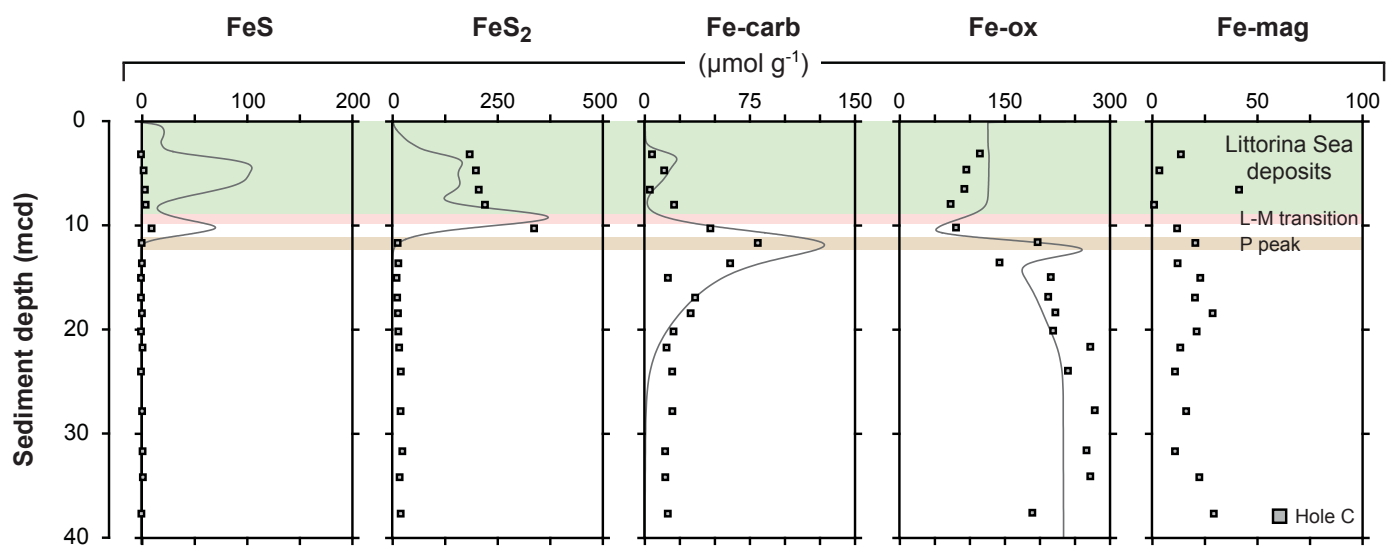

Figure 5. Trends in $\mathrm{S}$ and Fe phases with sediment depth for hole $\mathrm{C}$. The $\mathrm{S}$ phases were extracted according to the procedure of Burton et al. (2008). Solid grey lines illustrate profiles derived from the diagenetic model. The Fe extraction of Poulton and Canfield (2005) was applied to determine Fe carbonates (Fe-carb), sedimentary Fe oxides (Fe-ox; sum of amorphous and more crystalline Fe oxides) and magnetite (Femag). Details on the colored areas can be found in the legend of Fig. 3. 


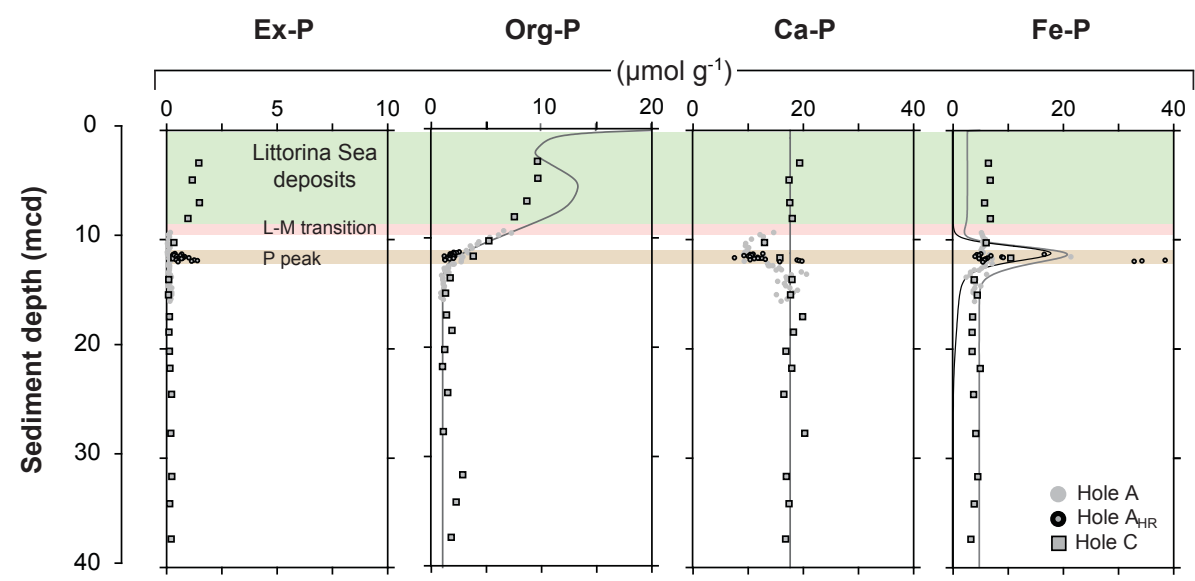

Figure 6. The phosphorus fractionation in the sediments for holes A and C, including exchangeable $\mathrm{P}(\mathrm{Ex}-\mathrm{P})$, organic $\mathrm{P}(\mathrm{Org}-\mathrm{P})$, authigenic and detrital Ca-P (Ca-P) and Fe-bound $\mathrm{P}(\mathrm{Fe}-\mathrm{P})$. Grey lines show profiles from our model (vivianite trend in black). These phosphorus phases were determined according to the P extraction method of Ruttenberg (1992), including modifications by Slomp et al. (1996). Hole A samples were taken from hole A cores more than 1 year after storage. More details on the colored areas can be found in the legend of Fig. 3.

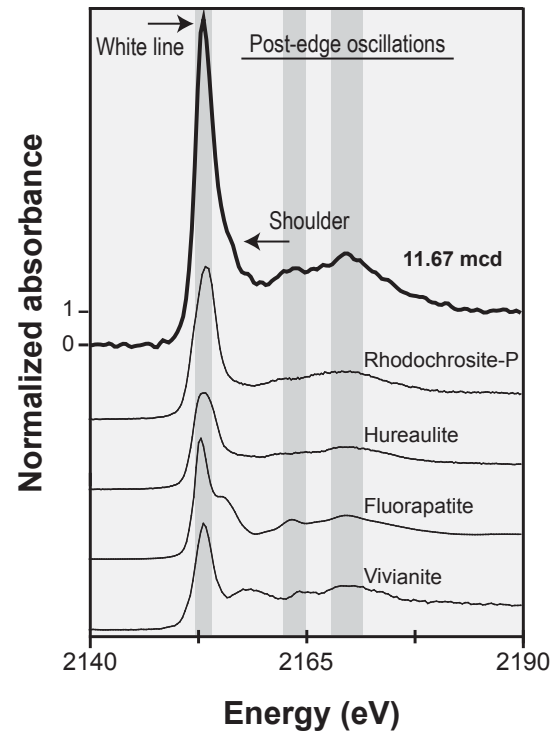

Figure 7. Unfocused P XANES spectra of bulk sediment from $11.67 \mathrm{mcd}$ (hole C) and various standards. All standards are described in Dijkstra et al. (2016). The dark grey shading highlights areas of specific interest. The positions of main features of the bulk sediment spectrum (the white line, post-edge shoulder and the postedge oscillations) are indicated in the figure. The white line (main absorption step) is observed in all $\mathrm{P}$ spectra, whereas the shoulder features are only visible in the bulk sediment spectrum and the fluorapatite spectrum.

duced a high initial release of $\mathrm{Fe}^{2+}$ into the porewater, leading to concentrations exceeding $6 \mathrm{mM}$. With no sulfide in the sediment and sufficient $\mathrm{PO}_{4}$ and $\mathrm{Fe}^{2+}$, conditions became favorable for vivianite authigenesis, and a distinct layer of this mineral formed. However, the continuous supply of $\mathrm{SO}_{4}^{2-}$ from the saline bottom water to the sediment and result- ing sulfide production consumed the majority of the $\mathrm{Fe}^{2+}$ such that it became depleted in the upper sediment around 6000 years BP and sulfide started to accumulate. No vivianite was formed in this sulfide-bearing zone and any vivianite present dissolved, as indicated by the temporal evolution of the rates of both processes (VF indicates vivianite formation; VD indicates vivianite dissolution). Dissolved $\mathrm{Fe}^{2+}$ was, however, still present at greater depths in the Ancylus Lake sediments and vivianite authigenesis continued at depth, limited by the supply of $\mathrm{PO}_{4}$ through downward diffusion. This formation is still ongoing and its current depthintegrated rate is estimated to be $0.0024 \mathrm{~mol} \mathrm{P} \mathrm{m}^{-2} \mathrm{yr}^{-1}$.

Between \pm 5000 and 2000 years BP, an enhanced Fe loading increased consumption of sulfide until the point where dissolved $\mathrm{Fe}^{2+}$ could build up again in the upper meter of the sediment, leading to a second zone of vivianite formation and a slowdown of vivianite dissolution below this ferruginous zone. With the drop in Fe loading at \pm 2000 years BP and the resulting buildup of sulfide, this surficial vivianite dissolved again, such that no remnants of it are currently visible in the sedimentary record.

\section{Discussion}

\subsection{The lake-marine transition in the Bornholm Basin}

Intrusion of North Sea water transformed the Ancylus Lake into the brackish-marine Littorina Sea $\sim 8000$ years ago (Andrén et al., 2011). This is in line with the trends in porewater salinity and $\mathrm{Mg}^{2+}$, a major constituent of seawater, which both indicate more marine conditions in the Bornholm Basin nowadays than during the early Holocene (Fig. 3). The lake-marine transition, as recorded in the biostratigraphy and lithology of our sediments between 9 and $10 \mathrm{mcd}$ (Sect. 2.1), 

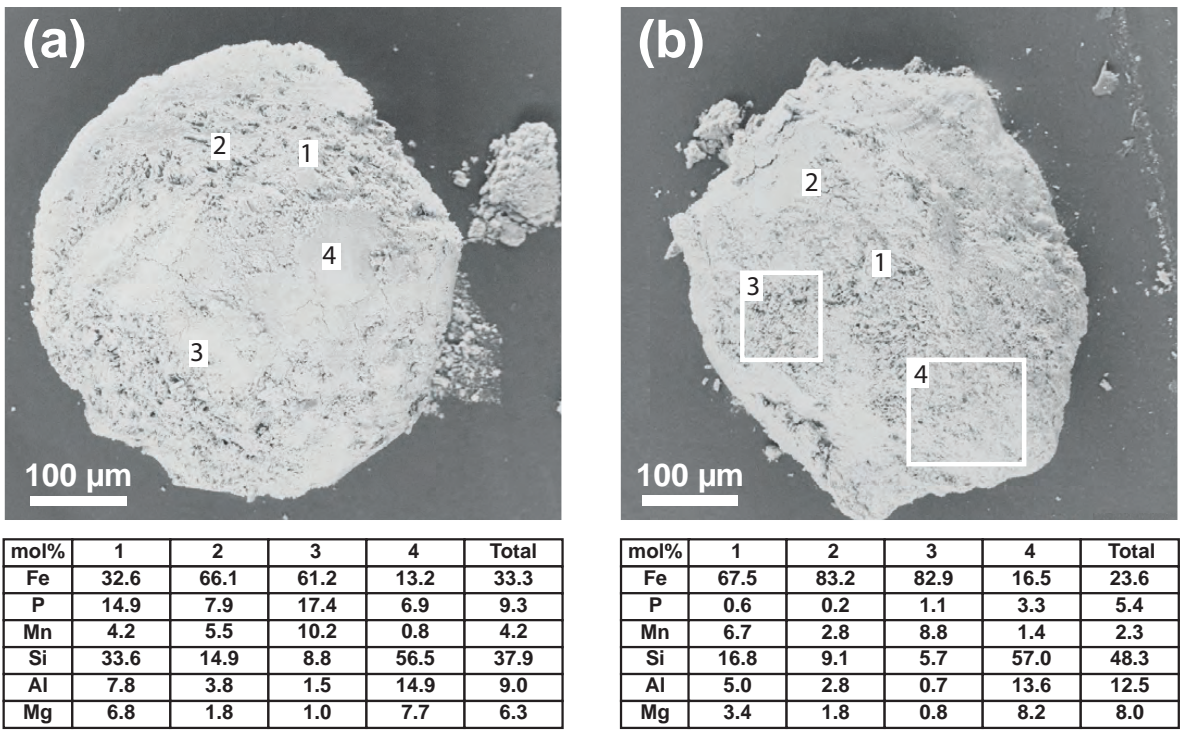

Figure 8. SEM-EDS images of blue aggregates from $11.98 \mathrm{mcd}$ (hole $\mathrm{A}_{\mathrm{HR}}$ ) with elemental concentrations in mol\%. The EDS results include analysis of spots and specific areas (1-5), and total area analysis.
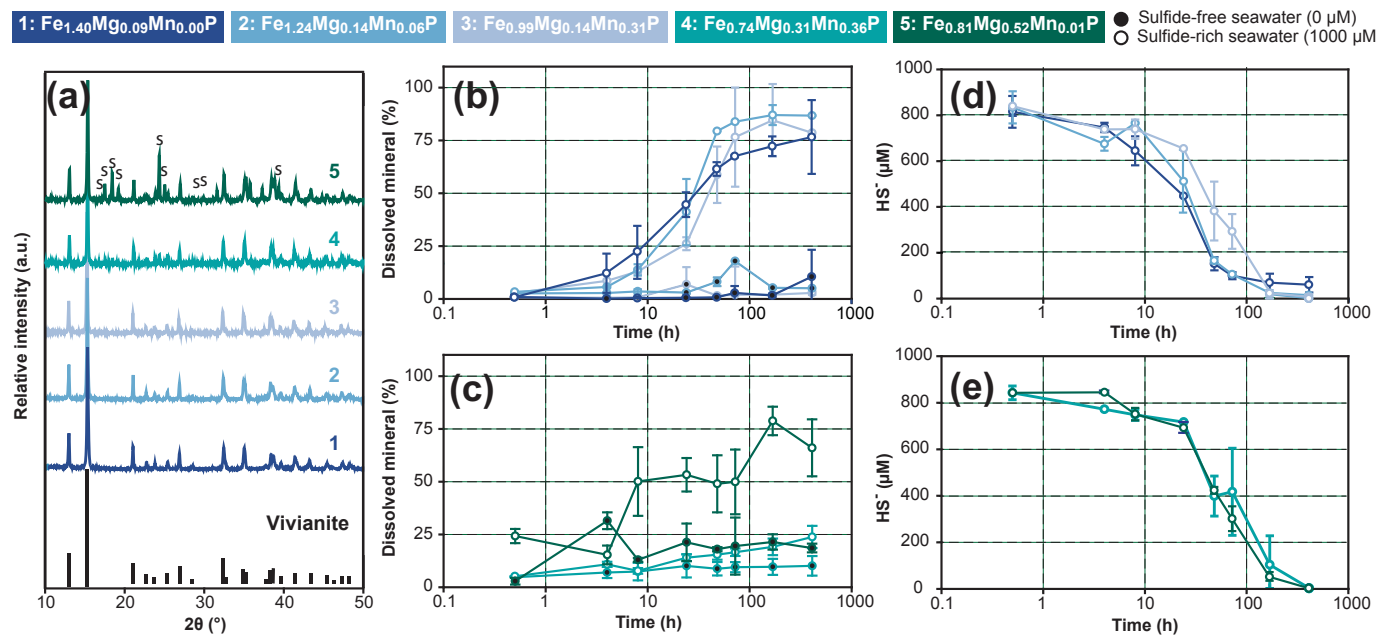

Figure 9. Results from the vivianite sulfidization experiment including the XRD spectra of the precipitates and vivianite (a), the percentage of dissolved phosphorus (P) mineral $(\mathbf{b}, \mathbf{c})$ and the sulfide $\left(\mathrm{HS}^{-}\right)$concentrations in the sample solutions (d, e). Error bars reveal standard deviations $(n=2)$ and sampling time is shown on a logarithmic scale. The XRD spectra of precipitates 4 and 5 also contained diffraction peaks that are indicative for struvite $(\mathrm{S})$. The sulfide concentrations in the samples with $0 \mu \mathrm{M}$ initially were all low $(<25 \mu \mathrm{M})$ and therefore not shown in the figure.

led to the deposition of $\mathrm{C}_{\mathrm{org}}$-rich sediments (Fig. 4). The decomposition of part of the organic matter resulted in the release of alkalinity, DIC, $\mathrm{NH}_{4}^{+}$and $\mathrm{PO}_{4}$ (Fig. 3) to the porewater. The slight increase in $\mathrm{C}_{\text {org }}$ before the lake-marine transition may be caused by enhanced water column productivity or by a lowering of the sedimentation rate due to decreased inputs of particulate matter in meltwater at that time, as proposed by Sohlenius et al. (1996). Such a shift in material supply may also explain the low concentrations of other terres- trial elements, such as $\mathrm{Fe}$ and $\mathrm{Mg}$, between 10 and $11.5 \mathrm{mcd}$ (Fig. 4) and the concurrent minimum in Ca-P (Fig. 6).

The Mo enrichments in the brackish-marine sediments at $9.5 \mathrm{mcd}$ ( $>0.3 \mu \mathrm{mol} \mathrm{g}^{-1}$; Fig. 4) are indicative of seasonally hypoxic and possibly euxinic bottom waters (Scott and Lyons, 2012). This period of low oxygen conditions coincided with the start of the Holocene Thermal Maximum just after the seawater intrusion when large parts of the Baltic Sea were experiencing bottom-water hypoxia (Jilbert et al., 2015; Zillén et al., 2008). In the Bornholm Basin, periodic 

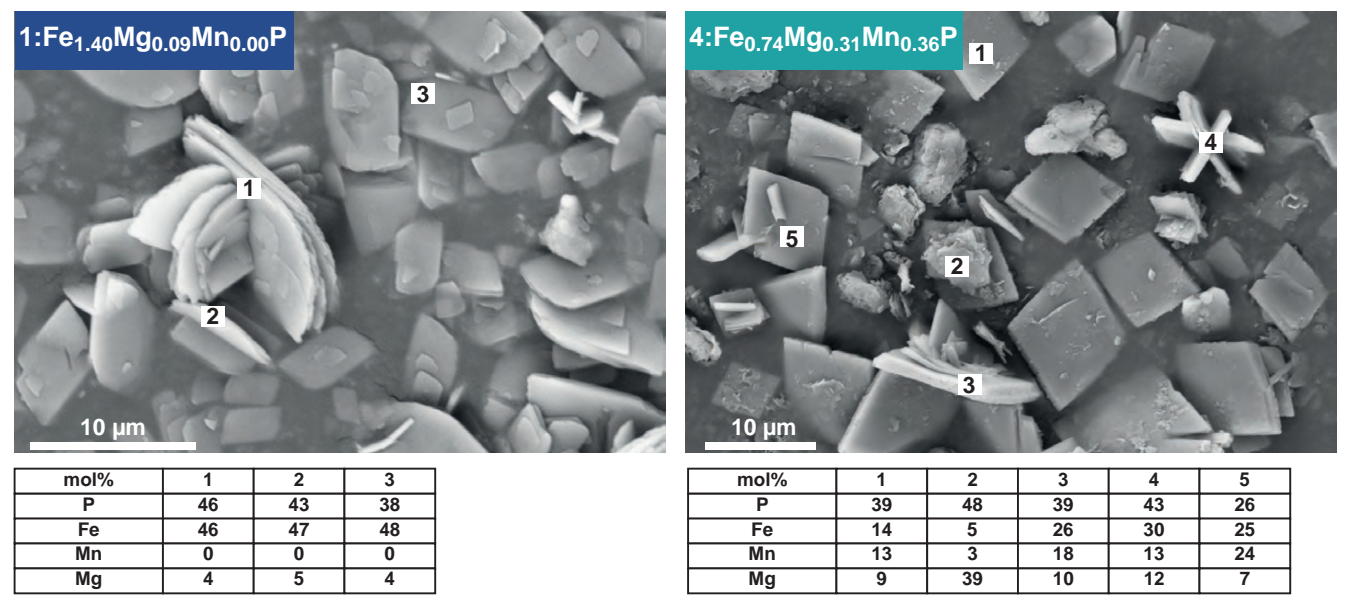

Figure 10. Examination of precipitates 1 and 4 at the start of the sulfidization experiment by SEM-EDS, including imaging and elemental concentrations in $\mathrm{mol} \%$. The precipitates also contained some sodium, chloride and sulfur (data are given in Table S1 in the Supplement).

inflows of oxygenated North Sea water at that time may have resulted in short periods of bottom-water oxygenation and, subsequently, Mn carbonates may have formed in the surface sediments from Mn oxides that precipitated onto the seafloor (Huckriede and Meischner, 1996; Lenz et al., 2015). Some Mo could also have been transported to the sediments adsorbed to these Mn oxides (Adelson et al., 2001; Algeo and Lyons, 2006), explaining our concurrent peak in Mo and Mn at $9.5 \mathrm{mcd}$ (Fig. 4). The sediments at $9.5 \mathrm{mcd}$ are also enriched in $\mathrm{Fe}$ and $\mathrm{S}$ due to the enhanced burial of $\mathrm{Fe}$ sulfides (Figs. 4 and 5). Furthermore, sediments elevated in Fe and $\mathrm{S}$ (as Fe sulfides) just below the lake-marine transition (Figs. 4 and 5) indicate that porewater sulfide diffused into the deeper lake sediments during the early Littorina Sea stage. Such sulfidization fronts are widely observed in sedimentary records of the Pleistocene and Holocene Baltic Sea (Boesen and Postma, 1988; Böttcher and Lepland, 2000; Holmkvist et al., 2014; Sohlenius et al., 1996).

\subsection{Post-depositional vivianite authigenesis below the lake-marine transition}

The distinct enrichments in $\mathrm{P}$ below the sulfidization front at $\sim 11.5 \mathrm{mcd}$ (Fig. 4) can be attributed to the presence of vivianite-type minerals in the sediments. Vivianite dissolves in the CDB-extraction step that targets Fe-bound P (Dijkstra et al., 2016; Nembrini et al., 1983) and may therefore be responsible for the enrichments in both Fe-P and total P (Figs. 4 and 6). Vivianite is also extracted in the hydroxylamine$\mathrm{HCl}$ step of the sequential $\mathrm{Fe}$ extraction and may thus explain our peak in sedimentary $\mathrm{Fe}$ oxides at $11.67 \mathrm{mcd}$ ( $\mathrm{Fe}-$ ox; Fig. 5). In addition, we discovered Fe-P aggregates in the P-rich sediments (Fig. 8) that were almost identical in shape, color and size to vivianite minerals synthesized by Zelibor et al. (1988). Our aggregates contained $\mathrm{Mg}$ and $\mathrm{Mn}$ (Fig. 8), which are impurities that have been observed in many vivianite minerals in marine and lake deposits (e.g., Dijkstra et al., 2016; Egger et al., 2015a; Hsu et al., 2014). The $\mathrm{P}$ content of the aggregates was low compared to the $\mathrm{Fe}$ content of the aggregates, resulting in $\mathrm{Fe}: \mathrm{P}$ ratios that are higher than the expected stoichiometric $\mathrm{Fe}: \mathrm{P}$ ratio of vivianite (>1.9 versus $\left.1.5 \mathrm{~mol} \mathrm{~mol}^{-1}\right)$. A similar discrepancy was observed in vivianite aggregates (as proven by XRD) in Dijkstra et al. (2016) and might reflect a surface coating of Fe, $\mathrm{Mn}$ and/or Mg of the aggregates, as has been observed in cold-seep sediments (Hsu et al., 2014). Finally, the reactive transport model also calculates a vivianite peak concurring with the observed enrichments in $\mathrm{P}$ at $\sim 11.5 \mathrm{mcd}$, while at the same time reproducing the trends in all key porewater and solid phase profiles (Figs. 3-6 and 11). Our sequential extractions, SEM-EDS and model analyses thus point towards the presence of vivianite in the P-rich sediments of the Bornholm Basin.

The presence of vivianite was, however, not confirmed by synchrotron-based XAS, as the bulk sediment P XANES spectrum (11.67 mcd; hole C) did not resemble the spectrum of our vivianite standard (Fig. 7). Instead, the post-edge oscillations of the sediment P XANES spectrum were typical for apatites (Fig. 7), even though the sediment is assumed to contain twice as much Fe-bound $\mathrm{P}$ compared to authigenic Ca-P (such as fluorapatite) (Fig. 6). This discrepancy between synchrotron-based and SEDEX-derived P fractionation might be caused by a bias of P XANES spectroscopy towards $\mathrm{P}$ species at particle surfaces, as has been proposed earlier by Dijkstra et al. (2016). As a consequence, the P XANES spectrum might mainly reflect a more disperse (apatite) pool instead of individual vivianite aggregates. This is line with the study of Egger et al. (2015a), in which P XANES spectroscopy was unable to conclusively identify vivianite in vivianite-rich surface sediments (as proven by XRD) in the Bothnian Sea. Due to this lack of direct evi- 

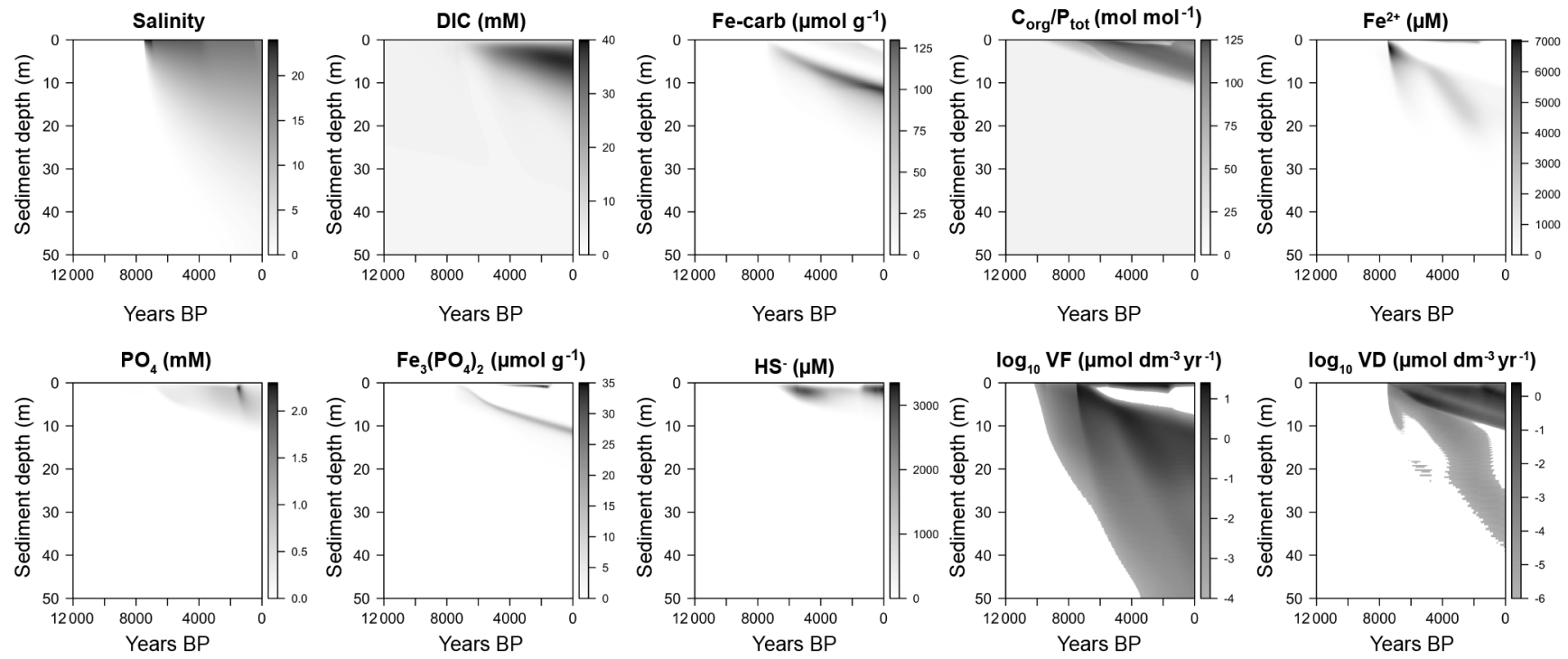

Figure 11. Modeled evolution of salinity, dissolved inorganic carbon (DIC), Fe carbonates (Fe-carb), $\mathrm{C}_{\text {org }} / \mathrm{P}_{\text {tot }}$, dissolved Fe (Fe ${ }^{2+}$ ), phosphate $\left(\mathrm{PO}_{4}\right)$, vivianite $\left(\mathrm{Fe}_{3}\left(\mathrm{PO}_{4}\right)_{2}\right)$, dissolved sulfide $\left(\mathrm{HS}^{-}\right)$and rates of vivianite formation $(\mathrm{VF})$ and vivianite dissolution $(\mathrm{VD})$ in the Bornholm Basin sediments from 12000 years BP to the present. A white color in the plots of VF and VD indicates values below the scale bar minimum. The increase in salinity at 7500 years BP marks the onset of the lake-marine transition. The subsequent deposition of sediment in a brackish-marine environment and the related changes in the porewater chemistry led to major changes in solid phase chemistry as a function of sediment depth and time. The distinct bands of $\mathrm{Fe}$ carbonate and vivianite $\left(\mathrm{Fe}_{3}\left(\mathrm{PO}_{4}\right)_{2}\right)$ minerals formed in the sediments are particularly striking.

dence for the presence of vivianite, we refer to the blue Fe-P aggregates as vivianite-type minerals.

\subsection{Post-depositional formation and stability of vivianite-type minerals}

In the Ancylus Lake sediments, iron(II) phosphate authigenesis occurs at the interface where downward-diffusing $\mathrm{PO}_{4}$, which is released by organic matter decomposition in the brackish-marine deposits, meets upward-diffusing $\mathrm{Fe}^{2+}$ (Fig. 3). The high $\mathrm{Fe}^{2+}$ concentrations in the Ancylus Lake sediments are assumed to be the result of reductive dissolution of $\mathrm{Fe}$ oxides in the lake sediments (Fig. 5) via organoclastic $\mathrm{Fe}$ reduction, Fe-mediated anaerobic oxidation of $\mathrm{CH}_{4}$ or a combination of both (Egger et al., 2017). Although porewater $\mathrm{PO}_{4}$ already began to accumulate in the surface sediments before the lake-marine transition, following the increase in organic matter inputs at 10500 years BP, the rate of iron(II)-phosphate formation resulting from this is insignificant compared to the authigenesis taking place directly after the lake-marine transition, explaining the fast increase in iron(II)-phosphate concentration at the interface with the lake sediments (Fig. 11).

A key variable in the temporal evolution of vivianite is the presence of free sulfide. Although it is currently not visible in the sedimentary record, the temporary second iron(II)-phosphate formation front active between 5000 and 2000 years BP (Fig. 11) had an important implication: it led to a disconnection of the major iron(II)-phosphate front from the active sulfidization front. The downward diffusion of sulfide shortly after the lake-marine transition promoted dissolution of freshly precipitated sedimentary iron(II) phosphates, resulting in a gradual migration of the iron(II)phosphate peak into deeper sediments below the lake-marine transition. This process was hindered by the increased $\mathrm{Fe}$ loading and resulting enhanced sulfide consumption, removing the tight connection between the sulfidization and iron(II)-phosphate fronts and decelerating the downward migration of the iron(II)-phosphate front over time. At present, porewater sulfide is restricted to the upper $5 \mathrm{~m}$ of sediment (Fig. 3), suggesting that the present iron(II)-phosphate peak is stable with respect to its position relative to the lakemarine transition (now at $11.5-12 \mathrm{mcd}$; Fig. 6). The location of the iron(II)-phosphate peak in the sediments thus depends on the susceptibility of the iron(II) phosphates to dissolution by dissolved sulfide and the extent of downward diffusion of sulfide. This key role for sulfide is also highlighted in our sulfidization experiment in which vivianite dissolves within $100 \mathrm{~h}$ in a seawater solution containing sulfide, also when it contains $\mathrm{Mn}$ or Mg (Fig. 9).

Free sulfide also determines the height and thickness of the iron(II)-phosphate peak, as is shown by a model run in which we assumed that no salinization took place (i.e., salinity was kept at its initial value for the entire model simulation time; Fig. 12). Under such conditions, a broad iron(II)-phosphate peak developed with a maximum at $\sim 6 \mathrm{mcd}$ and a depth- 


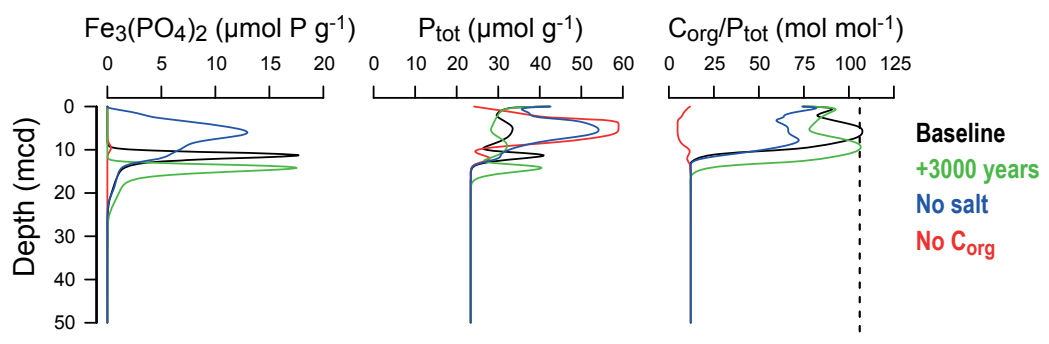

Figure 12. Sensitivity of vivianite, total $P$ concentration and the $C_{o r g}: P$ ratio in the sediments to changes in salinity and productivity from 12000 years BP to present, as well as 3000 years in the future with the current parameterization.

integrated concentration twice as high as in the default model run, as no sulfide-induced dissolution of iron(II) phosphate took place. The stability of the iron(II)-phosphate enrichment relative to the lake-marine transition is confirmed by running the model for an additional 3000 years without any changes in environmental conditions (Fig. 12). Over the course of this simulation, the continuous supplies of $\mathrm{PO}_{4}$ from above and $\mathrm{Fe}^{2+}$ from below the front led to an increase in the depth-integrated iron(II)-phosphate concentration from 20.4 to $25.2 \mathrm{~mol} \mathrm{P} \mathrm{m}^{-2}$. A final model sensitivity analysis emphasizes the key role of enhanced productivity and associated organic matter deposition on iron(II)-phosphate formation. If the organic matter loading is kept at its initial value for the last 10500 years, only a very small amount of iron(II) phosphates forms at the lake-marine transition (Fig. 12).

Note that we synthesized struvite together with vivianite in our sulfidization experiment (precipitates 4 and 5; Table 3; Figs. 9-10). In contrast to vivianite, struvite is observed in sulfide-rich waste water (e.g., Charles et al., 2006) and may thus be stable in the presence of sulfide. This is confirmed by our sulfidization experiment, in which, for example, only $25 \%$ of precipitate 4 (estimated struvite fraction: $20 \mathrm{~mol} \%$ P) dissolved in sulfide-rich seawater (Fig. 9). Struvite is observed in freshwater sediments (Cohen and Ribbe, 1966; Donovan and Grimm, 2007; Pi et al., 2010), and porewater saturation calculations indicate that struvite might also be present in some brackish-marine systems (e.g., Kau Bay and Saanich Inlet; Middelburg, 1990; Murray et al., 1978). In order for struvite to precipitate, porewaters need to be elevated in $\mathrm{NH}_{4}^{+}$and $\mathrm{PO}_{4}$ and have high molar $\mathrm{Mg} / \mathrm{Ca}$ porewater ratios (e.g., above $580 \mathrm{~mol} \mathrm{~mol}^{-1}$ by pH 7.6-7.9 and a $\mathrm{PO}_{4}$ concentration of $10 \mu \mathrm{M}$; Gull and Pasek, 2013), conditions that are not met in the Bornholm Basin (Fig. 3). So although struvite precipitation may affect $\mathrm{P}$ burial in other settings, it likely does not affect iron(II)-phosphate authigenesis in sediments of the Bornholm Basin.

\subsection{Implications for sedimentary $P$ records}

The presence of post-depositional vivianite-type minerals in sediments below the lake-marine transition is a widespread phenomenon in the Baltic Sea (Fig. 13). Vivianite has been

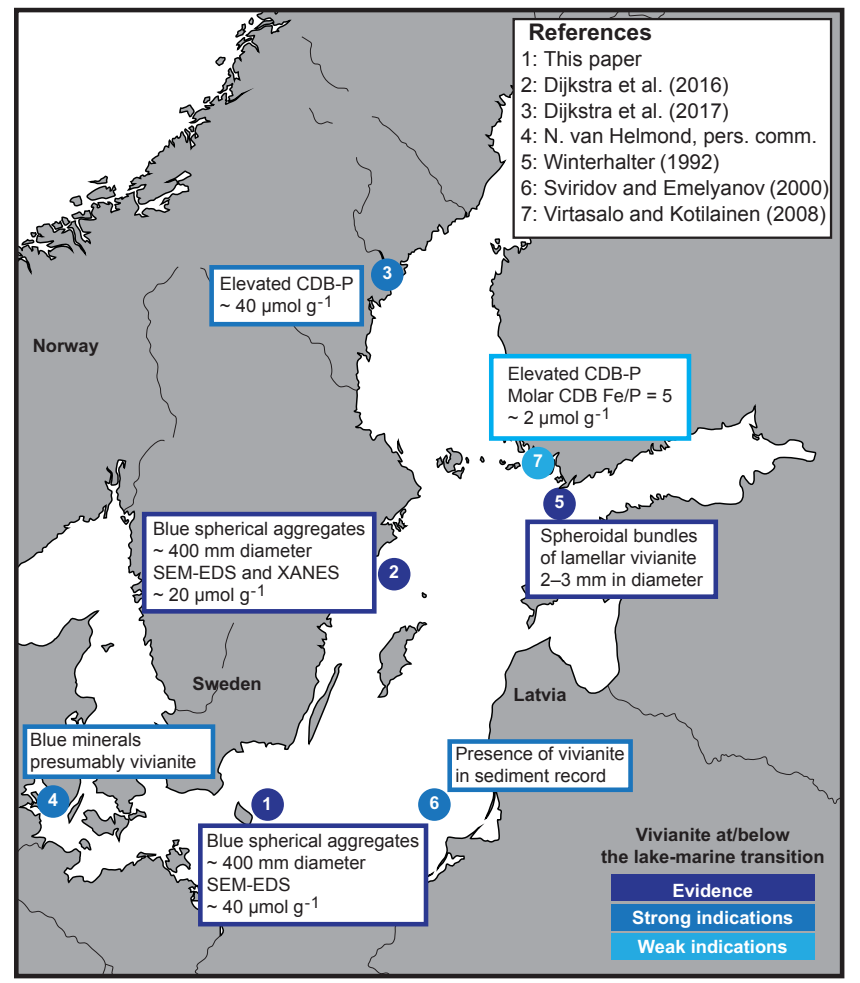

Figure 13. Locations in the Baltic Sea where vivianite is or might be present at or below the lake-marine transition from Ancylus Lake sediments to Littorina Sea sediments (see Sect. 4.4 for further explanation). Phosphorus (P) forms that dissolve in a citrate-dithionitebicarbonate extraction (CDB-P) are generally assumed to represent iron-bound $\mathrm{P}(\mathrm{Fe}-\mathrm{P})$.

observed below the lake-marine transition in the Landsort Deep (Dijkstra et al., 2016), in the Gulf of Finland (Winterhalter, 1992) and in the southern Baltic Sea (Sviridov and Emelyanov, 2000). Vivianite is also likely present in Ancylus Lake sediments in the coastal Bothnian Sea (Dijkstra et al., 2017a) and may explain the enrichments in CDB-extractable $\mathrm{P}$ (Fe-bound $\mathrm{P}$ ) in lake sediments from the Archipelago Sea in the northern Baltic Sea (Virtasalo and Kotilainen, 2008) and the large centimeter-scale blue aggregates observed in Ancylus Lake sediments in the Little 


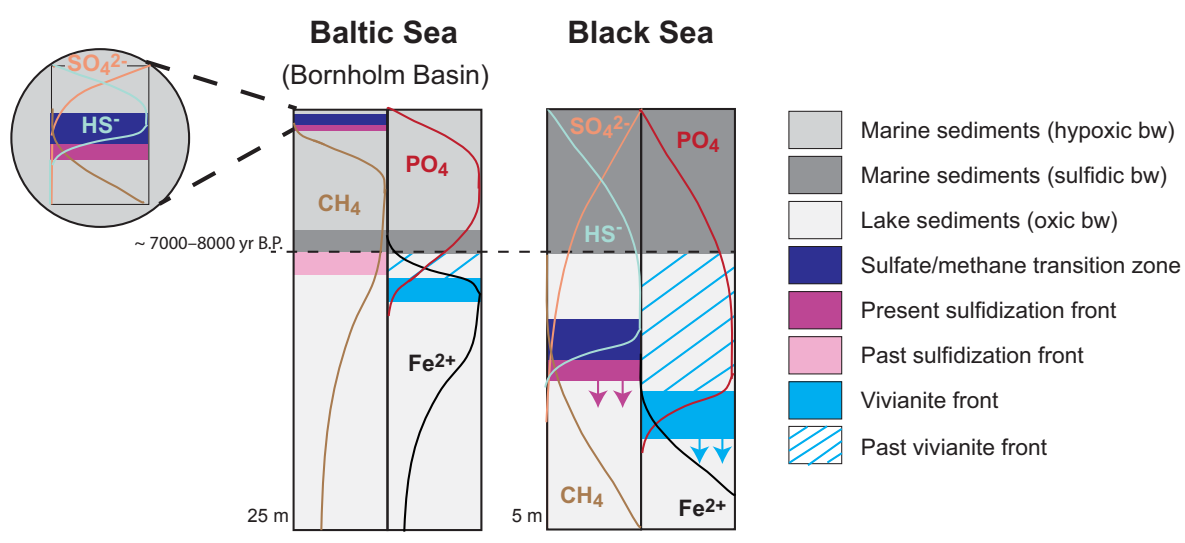

Figure 14. Simplified schematic of methane $\left(\mathrm{CH}_{4}\right)$, sulfur $(\mathrm{S})$, iron $(\mathrm{Fe})$ and phosphorus $(\mathrm{P})$ diagenesis in Baltic Sea (Bornholm Basin) and Black Sea sediments (see Sect. 4.4. for further explanation). Whereas the sedimentary vivianite peak in the Bornholm Basin is currently stable with respect to its position relative to the lake-marine transition, the peak in post-depositional vivianite in the Black Sea sediment is still migrating downwards from its initial location at the lake-marine transition (see Sect. 4.4). The formation of vivianite acts as a major sink for $\mathrm{PO}_{4}$ in the lake sediments, whereas the trend in porewater $\mathrm{Fe}^{2+}$ is affected mostly by upward diffusion and, for the Black Sea, also by removal with sulfide. The vivianite diagenesis in deep basin sediments of the Black Sea is discussed in detail by Egger et al. (2016). Note the difference in sediment depth between the Bornholm Basin and the Black Sea sediment record.

Belt, Denmark (Niels van Helmond, personal communication, 2017).

Vivianite-type minerals may also have precipitated at depth in sediments of other basins that have experienced past variations in salinity and productivity. For instance, large spherical vivianite aggregates have been found in Laptev Sea sediments (Taldenkova et al., 2010). These crystals were detected below sediments that were deposited during a period of enhanced water column primary productivity (as reflected by abundant ostracods; Stepanova et al., 2012). Vivianite in the Laptev Sea may thus have formed post-depositionally as a result of a change in primary productivity.

In our study, we clearly demonstrate that post-depositional formation of vivianite-type minerals can result in sediment $P$ enrichments that do not reflect changes in primary productivity and $\mathrm{P}$ burial at the time of sediment deposition. In the Bornholm Basin, this has led to a near doubling of the total $\mathrm{P}$ concentration in the sediment. Post-depositional $\mathrm{P}$ mineral formation can also result in a distinct lowering of the $\mathrm{C}_{\text {org }}: \mathrm{P}$ ratio. In our sediments, the increase in $\mathrm{P}$ coincides with an increase in $\mathrm{C}_{\text {org }}$, making this change less visible (Fig. 4). We conclude that the presence of post-depositional vivianitetype minerals should be considered when interpreting sedimentary records of $\mathrm{P}$ in systems that are subject to environmental perturbations (e.g., shifts in primary productivity).

The long-term stability of post-depositional iron(II) phosphates and their vertical location in sediments is controlled by the $\mathrm{Fe}, \mathrm{S}$ and $\mathrm{CH}_{4}$ dynamics in the sediments. This is illustrated by a simplified schematic of sediment and porewater profiles from the Bornholm Basin and from the sulfidic deep basin of the Black Sea (Fig. 14). A key difference between both systems is the location of the present sulfidization zone relative to the post-depositional iron(II)- phosphate peak in the sediment. In the Bornholm Basin, a sulfate/methane transition zone that is located above the lake-marine transition prohibits diffusion of sulfide into the underlying lake sediments. Due to the subsequent lack of sulfide in the lake sediments, the present iron(II)-phosphate peak is stable with respect to its position relative to the lakemarine transition and, under the same environmental conditions, will continue to grow at this location where downwarddiffusing $\mathrm{PO}_{4}$ meets upward-diffusing $\mathrm{Fe}^{2+}$ (Fig. 12). The deep basin of the Black Sea is characterized by lower sedimentation rates and higher bottom-water sulfide concentrations than the Bornholm Basin and, as a consequence, sulfide is diffusing into the lake sediments, promoting a downwardmigrating iron(II)-phosphate front. As has already been discussed in detail by Egger et al. (2016), the vivianite front in the Black Sea has already migrated more than $2 \mathrm{~m}$ below its initial location at the lake-marine transition.

\section{Conclusions}

In the Bornholm Basin, the presence of vivianite-type aggregates results in a distinct peak in total $\mathrm{P}\left(>40 \mu \mathrm{mol} \mathrm{g}{ }^{-1}\right)$ in the sediment record. These P-bearing minerals form postdepositionally below the lake-marine transition in the sediments, where $\mathrm{PO}_{4}$ from the marine organic-rich sediments meets dissolved $\mathrm{Fe}^{2+}$ from the lake sediments. This iron(II)phosphate front in the Bornholm Basin has migrated $\sim 1.5 \mathrm{~m}$ downwards from its initial location at the lake-marine transition. At present, it is a stable feature in the lake sediments of the Bornholm Basin. Post-depositional vivianitetype minerals may also have formed in other lake and marine basins that are subject to environmental perturbation, such 
as a change in primary productivity, which can be associated with a lake-marine transition. The possibility of postdepositional formation of vivianite-type minerals should thus be considered when using sediment $P$ proxies to reconstruct paleo-environmental conditions in coastal basins.

Data availability. The data files are available from the PANGAEA database (https://doi.org/10.1594/PANGAEA.880135; Dijkstra et al., 2017b) or are already published in Egger et al. (2017) or Andrén et al. (2015).

\section{The Supplement related to this article is available online at https://doi.org/10.5194/bg-15-861-2018-supplement.}

Competing interests. The authors declare that they have no conflict of interest.

Acknowledgements. This research was funded by the European Research Council under the European Community's Seventh Framework Programme (FP7/2007-2013)/ERC Starting Grant 278364 and the Netherlands Organisation for Scientific Research (NWO Vici grant 865.13.005). This research used samples and/or data provided by the Integrated Ocean Drilling Program (IODP). We thank the captain, crew and scientists of the IODP Expedition 347 aboard the Greatship Manisha from 12 September until 1 November 2013 and the scientists that were part of the onshore IODP 347 science party from 22 January to 20 February 2014. Also the captain, crew and scientists aboard R/V Pelagia from 28 May to 15 June 2016 (cruise 64PE411) are thanked. We also acknowledge the European Synchrotron Facility for providing beamtime at ID21. The reviewers are thanked for their constructive feedback. We further thank Camille Rivard for her assistance at the beamlines and Erik Smedberg for providing us with the Baltic Sea bathymetric map. We also thank Fieke Mulders for her assistance with the sulfidization experiment and SEDEX.

Edited by: Silvio Pantoja

Reviewed by: two anonymous referees

\section{References}

Adelson, J., Helz, G., and Miller, C.: Reconstructing the rise of recent coastal anoxia; molybdenum in Chesapeake Bay sediments, Geochim. Cosmochim. Ac., 65, 237-252, 2001.

Algeo, T. J. and Ingall, E.: Sedimentary $\mathrm{C}_{\text {org }}: \mathrm{P}$ ratios, paleocean ventilation, and Phanerozoic atmospheric $\mathrm{pO}_{2}$, Palaeogeogr. Palaeocl., 256, 130-155, https://doi.org/10.1016/j.palaeo.2007.02.029, 2007.

Algeo, T. J. and Lyons, T. W.: Mo-total organic carbon covariation in modern anoxic marine environments: Implications for analysis of paleoredox and paleohydrographic conditions, Paleoceanography, 21, PA1016, https://doi.org/10.1029/2004PA001112, 2006.
Alvarez, M., Rueda, E., and Sileo, E.: Simultaneous incorporation of $\mathrm{Mn}$ and $\mathrm{Al}$ in the goethite structure, Geochim. Cosmochim. Ac., 71, 1009-1020, 2007.

Andrén, T., Björck, S., Andrén, E., and Conley, D.: The development of the Baltic Sea Basin during the last $130 \mathrm{ka}$, in: The Baltic Sea Basin, edited by: Harff, J., Björck, S., and Hoth, P., 75-97, Springer-Verlag, Berlin, 2011.

Andrén, T., Jørgensen, B. B., Cotterill, C., Green, S., and Expedition 347 Scientists: Proc. IODP, 347, College Station, TX (Integrated Ocean Drilling Program), 2015.

APHA: Standard methods for the examination of water and wastewater, American Public Health Association - American Water Works Association - Water Environment Federation, 2005.

Arndt, S., Jørgensen, B. B., LaRowe, D. E., Middelburg, J. J., Pancost, R. D., and Regnier, P.: Quantifying the degradation of organic matter in marine sediments: A review and synthesis, Earth-Sci. Rev., 123, 53-86, https://doi.org/10.1016/j.earscirev.2013.02.008, 2013.

Berg, P., Rysgaard, S., and Thamdrup, B.: Dynamic modeling of early diagenesis and nutrient cycling. A case study in an arctic marine sediment, Am. J. Sci., 303, 905-955, 2003.

Berner, R.: A new geochemical classification of sedimentary environments, J. Sediment. Res., 51, 359-365, 1981.

Björck, S.: A review of the history of the Baltic Sea, 13.0-8.0 ka BP, Quarternary Int., 27, 19-40, 1995.

Boesen, C. and Postma, D.: Pyrite formation in anoxic environments of the Baltic, Am. J. Sci., 288, 575-603, 1988.

Böttcher, M. E. and Lepland, A.: Biogeochemistry of sulfur in a sediment core from the west-central Baltic Sea: Evidence from stable isotopes and pyrite textures, J. Mar. Syst., 25, 299-312, https://doi.org/10.1016/S0924-7963(00)00023-3, 2000.

Boudreau, B.: The diffusive tortuosity of fine-grained unlithified sediments, Geochim. Cosmochim. Ac., 60, 3139-3142, 1996.

Boudreau, B.: Diagenetic models and their implementation, Vol. 505, Springer, Berlin, 1997.

Burton, E. D., Sullivan, L. A., Bush, R. T., Johnston, S. G., and Keene, A. F.: A simple and inexpensive chromium-reducible sulfur method for acid-sulfate soils, Appl. Geochem., 23, 27592766, https://doi.org/10.1016/j.apgeochem.2008.07.007, 2008.

Calvert, S. E. and Pedersen, T. F.: Chapter Fourteen Elemental Proxies for Palaeoclimatic and Palaeoceanographic Variability in Marine Sediments: Interpretation and Application, Dev. Mar. Geol., 1, 567-644, https://doi.org/10.1016/S15725480(07)01019-6, 2007.

Canfield, D., Raiswell, R., and Bottrell, S.: The reactivity of sedimentary iron minerals toward sulfide, Am. J. Sci., 292, 659-683, 1992.

Charles, W., Cord-Ruwisch, R., Ho, G., Costa, M., and Spencer, P.: Solutions to a combined problem of excessive hydrogen sulfide in biogas and struvite scaling, Water Sci. Technol., 53, 203-211, 2006.

Cline, J. J. D.: Spectrophotometric Determination of Hydrogen Sulfide in Natural Waters, Limnol. Oceanogr., 14, 454-458, https://doi.org/10.4319/lo.1969.14.3.0454, 1969.

Cohen, L. H. and Ribbe, P. H.: Magnesium phosphate mineral replacement at Mono Lake, California, Am. Mineral., 51, 17551765, 1966.

Derkachev, A. N., Nikolaeva, N. A., Mozherovsky, A. V., Grigor'eva, T. N., Ivanova, E. D., Pletnev, S. P., Barinov, N. N., 
and Chubarov, V. M.: Mineralogical and geochemical indicators of anoxic sedimentation conditions in local depressions within the Sea of Okhotsk in the Late Pleistocene-Holocene, Russ. J. Pac. Geol., 1, 203-229, 2007.

Dickson, A. G., Sabine, C. L., and Christian, J. R.: Guide to best practices for ocean $\mathrm{CO}_{2}$ measurements, PICES Spec. Publ., 119, c269-c274, https://doi.org/10.1159/000331784, 2007.

Dijkstra, N., Kraal, P., Kuypers, M. M. M., Schnetger, B., and Slomp, C. P.: Are iron-phosphate minerals a sink for phosphorus in anoxic Black Sea sediments?, PLoS One, 9, e101139, https://doi.org/10.1371/journal.pone.0101139, 2014.

Dijkstra, N., Slomp, C., Behrends, T., and Expedition 347 Scientists: Vivianite is a key sink for phosphorus in sediments of the Landsort Deep, an intermittently anoxic deep basin in the Baltic Sea, Chem. Geol., 438, 58-72, 2016.

Dijkstra, N., Quintana Krupinski, N. B., and Slomp, C. P.: Holocene refreshening and reoxygenation of a Bothnian Sea estuary led to enhanced phosphorus burial, Estuar. Coast., 41, 139-157, https://doi.org/10.1007/s12237-017-0262-x, 2017a.

Dijkstra, N., Hagens, M., Egger, M., and Slomp, C. P.: Pore water and solid-phase measurements on sediment core 347-M0065 from the Bornholm Basin, Pangea, https://doi.org/10.1594/PANGAEA.880135, 2017b.

Donovan, J. J. and Grimm, E. C.: Episodic struvite deposits in a Northern Great Plains flyway lake: indicators of mid-Holocene drought?, Holocene, 17, 1155, https://doi.org/10.1177/0959683607082556, 2007.

Egger, M., Rasigraf, O., Sapart, C. J., Jilbert, T., Jetten, M. S. M., Röckmann, T., Van Der Veen, C., Banda, N., Kartal, B., Ettwig, K. F., and Slomp, C. P.: Iron-mediated anaerobic oxidation of methane in brackish coastal sediments, Environ. Sci. Technol., 49, 277-283, https://doi.org/10.1021/es503663z, 2015 a.

Egger, M., Jilbert, T., Behrends, T., Rivard, C., and Slomp, C. P.: Vivianite is a major sink for phosphorus in methanogenic coastal surface sediments, Geochim. Cosmochim. Ac., 169, 217-235, https://doi.org/10.1016/j.gca.2015.09.012, 2015b.

Egger, M., Kraal, P., Jilbert, T., Sulu-Gambari, F., Sapart, C. J., Röckmann, T., and Slomp, C. P.: Anaerobic oxidation of methane alters sediment records of sulfur, iron and phosphorus in the Black Sea, Biogeosciences, 13, 5333-5355, https://doi.org/10.5194/bg-13-5333-2016, 2016.

Egger, M., Hagens, M., Sapart, C. J., Dijkstra, N., van Helmond, N. A. G. M., Mogollón, J., Risgaard-Petersen, N., Van Der Veen, C., Kasten, S., Riedinger, N., Böttcher, M. E., Röckmann, T., Jørgensen, B. B., and Slomp, C. P.: Iron oxide reduction in methanerich deep Baltic Sea sediments, Geochim. Cosmochim. Ac., 207, 256-276, 2017.

Frost, R. L., Martens, W., Williams, P. A., and Kloprogge, J. T.: Raman and infrared spectroscopic study of the vivianite-group phosphates vivianite, baricite and bobierrite, Mineral. Mag., 66, 1063-1073, https://doi.org/10.1180/0026461026660077, 2002.

Ganeshram, R. S., Pedersen, T. F., Calvert, S., and François, R.: Reduced nitrogen fixation in the glacial ocean inferred from changes in marine nitrogen and phosphorus inventories, Nature, 415, 156-159, https://doi.org/10.1038/415156a, 2002.

Grasshoff, K., Ehrhardt, M., and Kremling, K. (Eds.): Methods of seawater analysis, 2nd Edn., Weinheim/Deerfield Beach, Florida, Verlag Chemie, 1983.
Gull, M. and Pasek, M. A.: Is Struvite a Prebiotic Mineral?, Life, 3 , 321-330, https://doi.org/10.3390/life3020321, 2013.

Hall, P. O. J. and Aller, R. C.: Rapid, small-volume, flow injection analysis for $\mathrm{SCO}_{2}$, and $\mathrm{NH}_{4}^{+}$in marine and freshwaters, Limnol. Oceanogr., 37, 1113-1119, https://doi.org/10.4319/lo.1992.37.5.1113, 1992.

Hindmarsh, A. C.: ODEPACK, A Systematized Collection of ODE Solvers, in: IMACS Transactions on Scientific Computation, Vol. 1, edited by: Stepleman, R. S., 55-64, Amsterdam, 1983.

Holmkvist, L., Kamyshny, A., Brüchert, V., Ferdelman, T. G., and Jørgensen, B. B.: Sulfidization of lacustrine glacial clay upon Holocene marine transgression (Arkona Basin, Baltic Sea), Geochim. Cosmochim. Ac., 142, 75-94, 2014.

Hsu, T., Jiang, W., and Wang, Y.: Authigenesis of vivianite as influenced by methane-induced sulfidization in cold-seep sediments off southwestern Taiwan, J. Asian Earth Sci., 89, 88-97, 2014.

Huckriede, H. and Meischner, D.: Origin and environment of manganese-rich sediments within black-shale basins, Geochim. Cosmochim. Ac., 60, 1399-1413, https://doi.org/10.1016/00167037(96)00008-7, 1996.

Ingall, E. D. and Jahnke, R.: Influence of water-column anoxia on the elemental fractionation of carbon and phosphorus during sediment diagenesis, Mar. Geol., 139, 219-229, https://doi.org/10.1016/S0025-3227(96)00112-0, 1997.

Ingall, E. D., Bustin, R. M., and Van Cappellen, P.: Influence of water column anoxia on the burial and preservation of carbon and phosphorus in marine shales, Geochim. Cosmochim. Ac., 57, 303-316, https://doi.org/10.1016/0016-7037(93)90433W, 1993.

Jensen, J. B., Moros, M., and Endler, R.: The Bornholm Basin, southern Scandinavia: a complex history from Late Cretaceous structural developments to recent sedimentation, Boreas, 46, 3 $17,2017$.

Jilbert, T. and Slomp, C. P.: Rapid high-amplitude variability in Baltic Sea hypoxia during the Holocene, Geology, 41, 11831186, https://doi.org/10.1130/G34804.1, 2013.

Jilbert, T., Slomp, C. P., Gustafsson, B. G., and Boer, W.: Beyond the Fe-P-redox connection: preferential regeneration of phosphorus from organic matter as a key control on Baltic Sea nutrient cycles, Biogeosciences, 8, 1699-1720, https://doi.org/10.5194/bg8-1699-2011, 2011.

Jilbert, T., Conley, D. J., Gustafsson, B. G., Funkey, C. P., and Slomp, C. P.: Glacio-isostatic control on hypoxia in a high-latitude shelf basin, Geology, 43, 427-430, https://doi.org/10.1130/G36454.1, 2015.

Kalniņa, L., Dreimanis, A., and Mūrniece, S.: Palynology and lithostratigraphy of Late Elsterian to Early Saalian aquatic sediments in the Ziemupe-Jūrkalne area, western Latvia, Quaternary Int., 68, 87-109, https://doi.org/10.1016/S1040-6182(00)000367, 2000 .

Kraal, P. and Slomp, C. P.: Rapid and Extensive Alteration of Phosphorus Speciation during Oxic Storage of Wet Sediment Samples, PLoS One, 9, e96859, https://doi.org/10.1371/journal.pone.0096859, 2014.

Kraal, P., Slomp, C. P., Forster, A., Kuypers, M. M. M., and Sluijs, A.: Pyrite oxidation during sample storage determines phosphorus fractionation in carbonate-poor anoxic sediments, Geochim. Cosmochim. Ac., 73, 3277-3290, https://doi.org/10.1016/j.gca.2009.02.026, 2009. 
Kraal, P., Slomp, C. P., and Lange, G. J. De: Sedimentary organic carbon to phosphorus ratios as a redox proxy in Quaternary records from the Mediterranean, Chem. Geol., 277, 167-177, https://doi.org/10.1016/j.chemgeo.2010.08.003, 2010.

Lenz, C., Jilbert, T., Conley, D. J., and Slomp, C. P.: Hypoxiadriven variations in iron and manganese shuttling in the Baltic Sea over the past $8 \mathrm{kyr}$, Geochem. Geophy. Geosy., 16, 37543766, https://doi.org/10.1002/2015GC005960, 2015.

Mackin, J. E. and Aller, R. C.: Ammonium adsorption in marine sediments, Limnol. Oceanogr., 29, 250-257, 1984.

März, C., Hoffmann, J., Bleil, U., de Lange, G. J., and Kasten, S.: Diagenetic changes of magnetic and geochemical signals by anaerobic methane oxidation in sediments of the Zambezi deep-sea fan (SW Indian Ocean), Mar. Geol., 255, 118-130, https://doi.org/10.1016/j.margeo.2008.05.013, 2008.

Meysman, F., Boudreau, B., and Middelburg, J.: Modeling reactive transport in sediments subject to bioturbation and compaction, Geochim. Cosmochim. Ac., 69, 3601-3617, 2005.

Middelburg, J.: Early diagenesis and authigenic mineral formation in anoxic sediments of Kau Bay, Indonesia, Geol. Ultraiectina, Faculteit Aardwetenschappen, Utrecht University, Utrecht, 1990.

Mohrholz, V., Dutz, J., and Kraus, G.: The impact of exceptionally warm summer inflow events on the environmental conditions in the Bornholm Basin, J. Mar. Syst., 60, 285-301, https://doi.org/10.1016/j.jmarsys.2005.10.002, 2006.

Moodley, L., Middelburg, J. J., Herman, P. M. J., Soetaert, K., and de Lange, G. J.: Oxygenation and organic-matter preservation in marine sediments: Direct experimental evidence from ancient organic carbon-rich deposits, Geology, 33, 889-892, https://doi.org/10.1130/G21731.1, 2005.

Murray, J. W., Grundmanis, V., and Smethie, W. M.: Interstitial water chemistry in the sediments of Saanich Inlet, Geochim. Cosmochim. Ac., 42, 1011-1026, https://doi.org/10.1016/00167037(78)90290-9, 1978.

Nakano, S.: Manganoan vivianite in the bottom sediments of Lake Biwa, Japan, Mineral. J., 16, 96-107, https://doi.org/10.2465/minerj.16.96, 1992.

Nembrini, G. P., Capobianco, J. A., Viel, M., and Williams, A. F.: A Mössbauer and chemical study of the formation of vivianite in sediments of Lago Maggiore (Italy), Geochim. Cosmochim. Ac., 47, 1459-1464, https://doi.org/10.1016/0016-7037(83)90304-6, 1983.

Nriagu, J. and Dell, C.: Diagenetic formation of iron phosphates in recent lake sediments, Am. Mineral., 59, 934-946, 1974.

Nriagu, J. O.: Stability of vivianite and ion-pair formation in the system $\mathrm{fe}_{3}\left(\mathrm{PO}_{4}\right)_{2}-\mathrm{H}_{3} \mathrm{PO}_{4} \mathrm{H}_{3} \mathrm{PO}_{4}-\mathrm{H}_{2} \mathrm{O}$, Geochim. Cosmochim. Ac., 36, 459-470, https://doi.org/10.1016/0016-7037(72)90035X, 1972.

Petzold, L.: Automatic selection of methods for solving stiff and nonstiff systems of ordinary differential equations, SIAM J. Sci. Stat. Comp., 4, 136-148, 1983.

Pi, T., Lozano-García, S., Caballero-Miranda, M., Ortega-Guerrero, B., and Roy, P.: Discovery and characterization of a struvite layer in the Chalco paleolake, Mexico, Rev. Mex. Cienc. Geol., 27, 573-580, https://doi.org/10.12957/geouerj.2015, 2010.

Poulton, S. and Canfield, D.: Development of a sequential extraction procedure for iron: implications for iron partitioning in continentally derived particulates, Chem. Geol., 214, 209-221, https://doi.org/10.1016/j.chemgeo.2004.09.003, 2005.
Ravel, B. and Newville, M.: ATHENA, ARTEMIS, HEPHAESTUS: data analysis for X-ray absorption spectroscopy using IFEFFIT, J. Synchrotron Radiat., 12, 537-41, https://doi.org/10.1107/S0909049505012719, 2005.

Reed, D. C., Slomp, C. P., and de Lange, G. J.: A quantitative reconstruction of organic matter and nutrient diagenesis in Mediterranean Sea sediments over the Holocene, Geochim. Cosmochim. Ac., 75, 5540-5558, https://doi.org/10.1016/j.gca.2011.07.002, 2011a.

Reed, D. C., Slomp, C. P., and Gustafsson, B. G.: Sedimentary phosphorus dynamics and the evolution of bottom-water hypoxia: A coupled benthic-pelagic model of a coastal system, Limnol. Oceanogr., 56, 1075-1092, https://doi.org/10.4319/lo.2011.56.3.1075, 2011 b.

Reed, D. C., Gustafsson, B. G., and Slomp, C. P.: Shelf-tobasin iron shuttling enhances vivianite formation in deep Baltic Sea sediments, Earth Planet. Sc. Lett., 434, 241-251, https://doi.org/10.1016/j.epsl.2015.11.033, 2016.

Rooze, J., Egger, M., Tsandev, I., and Slomp, C. P.: Iron-dependent anaerobic oxidation of methane in coastal surface sediments: Potential controls and impact, Limnol. Oceanogr., 61, S267-S282, 2016.

Rouzies, D., Millet, J. M. M., Lyon, I., Einstein, A., and Cedex, F. V.: Mossbauer study of synthetic oxidized vivianite at room temperature, Hyperfine Interact., 77, 19-28, 1993.

Ruttenberg, K. C.: Development of a sequential extraction method for different forms of phosphorus in marine sediments, Limnol. Oceanogr., 37, 1460-1482, 1992.

Ruttenberg, K. C.: The global phosphorus cycle, in: Treatise on geochemistry 8, 585-643, 2003.

Ruttenberg, K. C. and Berner, R. A.: Authigenic apatite formation and burial in sediments from non-upwelling, continental margin environments, Geochim. Cosmochim. Ac., 57, 991-1007, https://doi.org/10.1016/0016-7037(93)90035-U, 1993.

Salomé, M., Cotte, M., Baker, R., Barrett, R., Benseny-Cases, N., Berruyer, G., Bugnazet, D., Castillo-Michel, H., Cornu, C., Fayard, B., Gagliardini, E., Hino, R., Morse, J., Papillon, E., Pouyet, E., Rivard, C., Solé, V. A., Susini, J., and Veronesi, G.: The ID21 Scanning X-ray Microscope at ESRF, J. Phys. Conf. Ser., 425, 182004, https://doi.org/10.1088/17426596/425/18/182004, 2013.

Sannigrahi, P. and Ingall, E.: Polyphosphates as a source of enhanced $P$ fluxes in marine sediments overlain by anoxic waters: Evidence from $31 \mathrm{P}$ NMR, Geochem. Trans., 6, 52-59, https://doi.org/10.1186/1467-4866-6-52, 2005.

Scott, C. and Lyons, T.: Contrasting molybdenum cycling and isotopic properties in euxinic versus non-euxinic sediments and sedimentary rocks: refining the paleoproxies, Chem. Geol., 324325, 19-27, 2012.

Slomp, C. P., Epping, E. H. G., Helder, W., and Raaphorst, W. Van: A key role for iron-bound phosphorus in authigenic apatite formation in North Atlantic continental platform sediments, J. Mar. Res., 54, 1179-1205, https://doi.org/10.1357/0022240963213745, 1996.

Slomp, C. P., Thomson, J., and de Lange, G. J.: Enhanced regeneration of phosphorus during formation of the most recent eastern Mediterranean sapropel (S1), Geochim. Cosmochim. Ac., 66, 1171-1184, https://doi.org/10.1016/S0016-7037(01)00848$1,2002$. 
Soetaert, K. and Herman, P. M.: "ecolMod": A practical guide to ecological modelling-using $\mathrm{R}$ as a simulation platform, $\mathrm{R}$ package version 1, available at: https://CRAN.R-project.org/ package=ecolMod (last access: 4 February 2018), 2009.

Soetaert, K. and Meysman, F.: Reactive transport in aquatic ecosystems: Rapid model prototyping in the open source software R, Environ. Model. Softw., 32, 49-60, 2012.

Soetaert, K., Petzoldt, T., and Meysman, F.: Marelac: Tools for aquatic sciences, available at: http://CRAN.R-project.org/ package $=$ marelac (last access: 4 February 2018), 2010a.

Soetaert, K., Petzoldt, T., and Setzer, R.: Solving differential equations in R: package deSolve, J. Stat. Softw., 33, 1-25, 2010 b.

Sohlenius, G., Sternbeck, J., Andrén, E., and Westman, P.: Holocene history of the Baltic Sea as recorded in a sediment core from the Gotland Deep, Mar. Geol., 134, 183-201, https://doi.org/10.1016/0025-3227(96)00047-3, 1996.

Sohlenius, G., Emeis, K., Andrén, E., Andrén, T., and Kohly, A.: Development of anoxia during the Holocene fresh-brackish water transition in the Baltic Sea, Mar. Geol., 177, 221-242, 2001.

Stepanova, A., Taldenkova, E., and Bauch, H. A.: Ostracod palaeoecology and environmental change in the Laptev and Kara seas (Siberian Arctic) during the last 18000 years, Boreas, 41, 557577, https://doi.org/10.1111/j.1502-3885.2012.00254.x, 2012.

Strickland, T. D. H. and Parsons, T. R.: A Practical Handbook of Seawater Analysis, Fisheries Research Board of Canada, Ottawa, 1972.

Sviridov, N. I. and Emelyanov, E. M.: Lithofacial complexes of quaternary deposits in the central and southeastern baltic sea, Lithol. Miner. Resour., 35, 211-231, https://doi.org/10.1007/BF02821956, 2000.

Taldenkova, E., Bauch, H. A., Gottschalk, J., Nikolaev, S., Rostovtseva, Y., Pogodina, I., Ovsepyan, Y., and Kandiano, E.: History of ice-rafting and water mass evolution at the northern Siberian continental margin (Laptev Sea) during Late Glacial and Holocene times, Quaternary Sci. Rev., 29, 3919-3935, https://doi.org/10.1016/j.quascirev.2010.09.013, 2010.

Tribovillard, N., Algeo, T. J., Lyons, T., and Riboulleau, A.: Trace metals as paleoredox and paleoproductivity proxies: An update, Chem. Geol., 232, 12-32, https://doi.org/10.1016/j.chemgeo.2006.02.012, 2006.
Tyrrell, T.: The relative influences of nitrogen and phosphorus on oceanic primary production, Nature, 400, 525-531, https://doi.org/10.1038/22941, 1999.

Virtasalo, J. J. and Kotilainen, A. T.: Phosphorus forms and reactive iron in lateglacial, postglacial and brackish-water sediments of the Archipelago Sea, northern Baltic Sea, Mar. Geol., 252, 1-12, https://doi.org/10.1016/j.margeo.2008.03.008, 2008.

Vuillemin, A., Ariztegui, D., De Coninck, A. S., Lücke, A., Mayr, C., Schubert, C. J., and Team, T. P. S.: Origin and significance of diagenetic concretions in sediments of Laguna Potrok Aike, southern Argentina, J. Paleolimnol., 50, 275-291, https://doi.org/10.1007/s10933-013-9723-9, 2013.

Wang, Y. and Van Cappellen, P.: A multicomponent reactive transport model of early diagenesis: Application to redox cycling in coastal marine sediments, Geochim. Cosmochim. Ac., 60, 2993 3014, 1996.

Westrich, J. and Berner, R.: The role of sedimentary organic matter in bacterial sulfate reduction: The G model tested, Limnol. Oceanogr., 29, 236-249, 1984.

Winterhalter, B.: Authigenic vivianite in lower Ancylus sediments in the western Gulf of Finland, in: Proceedings of the Second Marine Geological Conference - The Baltic, Rostock, 21-26 October 1991, edited by: Lemke, W., Lange, D., and Endler, R., Institut für Ostseeforschung Warnemunde, 1992.

Zelibor, J., Senftle, F., and Reinhardt, J.: A proposed mechanism for the formation of spherical vivianite crystal aggregates in sediments, Sediment. Geol., 59, 125-142, 1988.

Zillén, L., Conley, D. J., Andrén, T., Andrén, E., and Björck, S.: Past occurrences of hypoxia in the Baltic Sea and the role of climate variability, environmental change and human impact, Earth-Sci. Rev., 91, 77-92, https://doi.org/10.1016/j.earscirev.2008.10.001, 2008. 